\title{
Recovery from Divorce: Comparing High and Low Income Couples
}

\author{
Hayley Fisher and Hamish Low
}

May 19, 2016

\begin{abstract}
This paper shows that divorce in the UK has different consequences for high and for low income households, and for men and for women. The opportunity to mitigate these consequences and to recover also differs across groups. Women in the highest income households before divorce suffer the largest and most persistent falls in their standard of living compared to those from the lowest income households, who recover quickly. Men increase their standard of living on divorce: low income men recover the most and recover fastest, partly driven by returning to live with their extended families. Across the income distribution, there is no evidence that women are more likely to remain in the marital home than men after divorce, with the majority of men and women moving house on divorce.
\end{abstract}




\section{Introduction}

In England and Wales, 42\% of marriages are expected to end in divorce (ONS 2012). Despite increases in the importance of unmarried cohabitation, the majority of families in England and Wales consist of a married couple with or without dependent children. Understanding the short and longer term impacts of divorce on household welfare, and how individuals smooth the associated shocks, is therefore important.

A wide literature has shown that the financial impact of divorce is greater for women than it is for men across developed countries. ${ }^{1}$ Moreover, the impact varies based on various pre-separation characteristics: for example, the negative impact for women is greater the smaller the individual's pre-separation share of household income and as the number of children increases. However, this research has focused on looking at average effects and this misses the differing experiences across the income distribution: how do the high income fare compared to the low income, and how do their mechanisms of support differ. There is also some concern that analysis of men's household income is incomplete and overestimates their standard of living after divorce (McManus and DiPrete 2001; Aassve et al. 2007), especially because of different access to housing. This paper addresses this gap and examines the implications of divorce for households in England and Wales, separating out the experiences of men and women, and considering the different experiences at different points in the pre-divorce household income distribution. We focus on the mechanisms behind the differences in observed household income trajectories, including labour supply, living arrangements, housing, welfare benefits and private transfers.

We use data from 18 waves of the British Household Panel Survey (BHPS) to examine changes around the time of divorce for men and women in three income groups. ${ }^{2}$ Our approach is complementary to Brewer and Nandi (2014) who use the same data to look at relationship breakdown more generally across the whole UK. We restrict attention to

\footnotetext{
${ }^{1}$ For England and Wales see Jarvis and Jenkins (1999), Jenkins (2008), Fisher and Low (2009) and Brewer and Nandi (2014); for the United States see Duncan and Hoffman (1985), Smock (1994), Holden and Smock (1991), Bianchi et al. (1999), McKeever and Wolfinger (2001); for Canada Gadalla (2008); for the Netherlands Poortman (2000); for Australia de Vaus et al. (2014); for Italy Ongaro et al. (2009); for Norway Bratberg and Tjøtta (2008); for France Bonnet et al. (2015); for comparative European evidence see Andreß et al. (2006) and Aassve et al. (2007).

2 Previous research has documented differences in the effects of relationship breakdown for married and unmarried couples (Avellar and Smock 2005; Manting and Bouman 2006; Fisher and Low 2015)
} 
married couples who are all subject to the same legal process of divorce in the event of relationship breakdown. The data spans the period from 1991 to 2008. Across groups, we compare changes in household income, adjusting for household size, and also changes in home ownership and the likelihood of moving home. We examine the mechanisms to mitigate the costs of divorce, analysing living arrangements, labour market activity, private transfers and government benefits, and considering the effects of different assumptions about income sharing within households.

Our conclusions are as follows: first, the financial consequence of divorce for men is less severe than for women, even after accounting for housing. However, among both men and women, those from high income households lose more and take longer to recover than those from low income households. This is in line with the findings of Brewer and Nandi (2014) who look at divorce and separation from cohabitation combined. Second, there is no evidence that women are more likely to stay in the marital home after divorce: $70 \%$ of men and $64 \%$ of women move house within 3 years of relationship breakdown, and this is similar across the income distribution. There is, however, evidence that women with dependent children at the time of divorce are more likely than their former husbands to remain in the marital home or to gain access to social housing. Third, in terms of mitigating losses, recovery is driven by repartnering, either in a new marriage or as informal cohabitation, across the income distribution: about $40 \%$ of women and of men have repartnered within 3 years of divorce. There is no significant response in labour supply for men or for women. This is in contrast to evidence from the US suggesting that labour supply responses are an important component of women's financial recovery after divorce (Tamborini et al. 2015). Government benefit income is especially important for women, with the middle and higher income groups seeing substantial and persistent increases in government benefit income in the aftermath of divorce. Finally, in the lower and middle income groups, men are 4.5 times more likely than women to live with their extended family in the aftermath of divorce, providing an important temporary living arrangement to smooth the household income consequences of divorce.

Of course these financial consequences of divorce do not give a full picture of the total costs incurred. Household income (even adjusted for household size) is an imperfect measure of wellbeing. To gain some insight into broader wellbeing consequences, we 
present results for scores in the General Health Questionnaire (GHQ), a measure of psychological wellbeing. This analysis shows that increases in mental distress immediately preceding and at the time of divorce are temporary, reverting to prebreakdown levels or lower within three years. This demonstrates a medium-term benefit from divorce which compensates for the fall in material resources.

The rest of the paper is structured as follows: section 2 describes the data source; section 3 shows the differences in income changes on divorce across the distribution and differences in access to housing; section 4 presents evidence on recovery mechanisms and how these differ across the distribution; section 5 shows evidence on the psychological effects of divorce and section 6 concludes.

\section{Data}

We use data from waves 1 to 18 (1990 to 2008) of the British Household Panel Survey (BHPS), a longitudinal survey of households in Great Britain. The BHPS ran for these eighteen years, before being superseded by Understanding Society, a larger and more wide- ranging survey. Our sample selection criteria limits our analysis to the BHPS data and so limits the time period we can study to the pre-financial crisis period. ${ }^{3}$ The first wave of the survey involved a nationally representative sample of 5,500 British households, covering around 10,300 adults. Members of these households are 'Original Sample Members' (OSM), and have been reinterviewed in each subsequent survey wave where possible. Individuals who enter the household of an OSM are also interviewed whilst coresident, and are added as 'Permanent Sample Members' (PSM) and followed in subsequent waves regardless of continuing coresidency if they have a child with an OSM. This allows us both to observe intact couples and to follow individuals over time if their relationship breaks down. ${ }^{4}$

\footnotetext{
${ }^{3}$ Over $80 \%$ of BHPS respondents joined the panel for Understanding Society, but were not interviewed again until 2011. As we require three years of pre-divorce data to assign a couple to an income group, the first additional divorce we could include would take place in 2013, leaving a five year gap in divorces and giving only one post-divorce observation for couples in Understanding Society. Therefore, we restrict our sample to the BHPS.

${ }^{4}$ Individuals who marry an OSM but do not have children before they divorce are not followed and so cannot be included.
} 
We limit our attention to individuals associated with original BHPS sample members residing in England and Wales who are observed to divorce during the survey period. ${ }^{5}$ So, for an individual to be included in our analysis sample, we must observe them married and residing with their spouse, and subsequently not residing with their spouse and reporting being separated or divorced. We select individuals aged between 20 and 60 at the time of divorce. ${ }^{6}$

The BHPS includes rich data on demographic characteristics, housing tenure, individual and household incomes and their sources, and household composition. Household financial resources is defined as total household income (adjusted for inflation) after subtracting any amounts reported to be transferred to individuals outside of the household. Private transfer income received by the household is included in this measure of household income, so post- divorce receipts of spousal periodical payments and child support are accounted for to the extent that they have been reported. More detail on these measures in our sample is reported in section 4.3.

A key component of this paper is the analysis of differing experiences at different parts of the income distribution. We define three income groups based on population-wide household income adjusted for household composition. We label income after this adjustment "equivalised income", and discuss how this adjustment is made in section 2.1. Using the complete BHPS sample of OSMs, we use longitudinal weights to calculate thresholds defining population-wide equivalised household income terciles by year. Using these thresholds, we classify our sample of divorcing individuals into one of the three household income groups based on their pre-divorce equivalised household income: these are labelled the "High income", "Middle income" and "Low income". We use average equivalised household income in the three years prior to divorce as a measure of the intact household's standard of living. We use the three year average because a drop in household income may precipitate divorce and so the last household

\footnotetext{
5 This excludes individuals from Scotland, and those from the Scotland, Wales and Northern Ireland extension samples.

${ }^{6}$ Whilst we draw from the same data as Brewer and Nandi (2014), our selection criteria differ: we consider only married couples, rather than pooling married and unmarried couples, and we exclude very young couples and couples above retirement age. Below, we note where these differences in sample selection result in different conclusions.
} 
income observation may be a very noisy measure of the standard of living. ${ }^{7} \mathrm{We}$ therefore require an individual to have responded to the survey in the three years prior to observed divorce and at least one year immediately after divorce to be included in our analysis sample. We include the responses of these individuals from all waves, allowing us to examine the longer term responses to the experience of relationship breakdown.

Applying these criteria leads to a sample of 273 men and 368 women with an average of 4.8 observations each in the six years after divorce is observed. There are two reasons why we do not observe the full 6 observations for each sample individual: first, if a divorce occurs towards the end of the sample period (say, in 2006), then that individual's observations will 'run out' due to the end of the survey in 2008. Second, attrition occurs between the waves of surveys through loss of contact or refusal. $61 \%$ of individuals from our sample provide observations through to six years post separation. Of the remainder, $53 \%$ (21\% of sample individuals) exit the sample due to the end of the survey in 2008 . Genuine attrition is seen for $18 \%$ of individuals in our sample. No predivorce characteristics consistently predict this attrition. Our sample also reflects a higher attrition rate for men than for women, which is typical for longitudinal surveys including the BHPS (Uhrig 2008).

Averages of observable characteristics for this analysis sample of households who we observe to divorce are given in columns 1 to 4 of Table 1 for the period immediately before the divorce occurs. ${ }^{8}$ We can see that, on average, divorcing men are older, more educated, have higher labour force participation and higher unemployment than divorcing women. The average relationship in our sample lasted around 12 years prior to divorce.

For comparison, columns 5 to 8 of Table 1 give average characteristics for all married couples responding to the BHPS (including those observed to divorce and those never observed to divorce). These observations are divided into the same income terciles to allow insight into the differential selection of married couples into divorce at different points in the income distribution.

\footnotetext{
7 The thresholds for the income groups are defined by population-weighted household income, based on average household income in the previous three years. Looking at just the year immediately preceding divorce does not change the conclusions presented below.

${ }^{8}$ Averages across the three years prior to divorce are not substantially different.
} 
A number of differences between the general population of married couples and divorcing couples are common across the income distribution: the divorcing population is younger and has more children. Divorcing men have lower individual labour income than married men, whereas divorcing women work more hours and contribute proportionately more to household income than married women. In total, therefore, there is little difference in absolute or equivalised household income between divorcing and married couples.

Table 1: Average Characteristics of the Divorcing Sample Pre-Divorce, and of All Married Couples

\begin{tabular}{|c|c|c|c|c|c|c|c|c|}
\hline & \multicolumn{4}{|c|}{ Divorcing sample } & \multicolumn{4}{|c|}{ All married couples } \\
\hline & All & $\begin{array}{c}\text { Low } \\
\text { Income }\end{array}$ & $\begin{array}{l}\text { Middle } \\
\text { Income }\end{array}$ & $\begin{array}{c}\text { High } \\
\text { Income }\end{array}$ & All & $\begin{array}{c}\text { Low } \\
\text { Income } \\
\end{array}$ & $\begin{array}{l}\text { Middle } \\
\text { Income }\end{array}$ & $\begin{array}{c}\text { High } \\
\text { Income }\end{array}$ \\
\hline \multicolumn{9}{|l|}{ Men } \\
\hline Age (years) & 38.9 & 39.3 & 38.8 & 38.6 & 43.6 & 42.5 & 43.8 & 43.9 \\
\hline Number of children & 1.3 & 1.9 & 1.3 & 0.9 & 1.0 & 1.5 & 1.0 & 0.7 \\
\hline High education* & 0.60 & 0.39 & 0.60 & 0.75 & 0.61 & 0.38 & 0.56 & 0.75 \\
\hline Not working* & 0.11 & 0.28 & 0.09 & 0.01 & 0.11 & 0.30 & 0.08 & 0.05 \\
\hline Hours worked per week & 37.6 & 29.0 & 39.2 & 42.3 & 36.8 & 30.0 & 38.0 & 38.9 \\
\hline Relationship tenure (years) & 12.4 & 12.7 & 12.5 & 12.0 & 15.9 & 15.2 & 16.6 & 15.7 \\
\hline Annual labour income $(£ 000)$ & 18.4 & 6.8 & 16.6 & 28.7 & 20.7 & 8.1 & 16.9 & 29.7 \\
\hline Annual household income $(£ 000)$ & 32.2 & 17.5 & 28.5 & 46.8 & 35.9 & 17.2 & 29.0 & 50.3 \\
\hline Annual eq. hh income $(£ 000)$ & 24.2 & 11.2 & 20.5 & 37.6 & 27.1 & 11.0 & 20.3 & 40.2 \\
\hline Share of hh income (proportion) & 0.61 & 0.53 & 0.62 & 0.67 & 0.63 & 0.62 & 0.64 & 0.63 \\
\hline Home owner* & 0.75 & 0.43 & 0.83 & 0.91 & 0.82 & 0.56 & 0.84 & 0.91 \\
\hline Number of observations & 273 & 74 & 99 & 100 & 25068 & 5014 & 9209 & 10845 \\
\hline Proportion & & 0.27 & 0.36 & 0.37 & & 0.20 & 0.37 & 0.43 \\
\hline \multicolumn{9}{|l|}{ Women } \\
\hline Age (years) & 36.6 & 36.4 & 36.7 & 36.6 & 42.6 & 41.7 & 42.8 & 42.8 \\
\hline Number of children & 1.3 & 1.8 & 1.2 & 0.8 & 0.9 & 1.4 & 0.9 & 0.6 \\
\hline High education* & 0.48 & 0.39 & 0.43 & 0.63 & 0.51 & 0.30 & 0.45 & 0.68 \\
\hline Not working* & 0.26 & 0.45 & 0.21 & 0.11 & 0.27 & 0.52 & 0.26 & 0.16 \\
\hline Hours worked per week & 22.5 & 14.2 & 23.5 & 30.1 & 20.5 & 11.1 & 20.0 & 25.8 \\
\hline Relationship tenure (years) & 12.6 & 13.4 & 12.8 & 11.6 & 17.3 & 17.0 & 18.0 & 16.7 \\
\hline Annual labour income $(£ 000)$ & 8.7 & 2.6 & 7.5 & 16.5 & 8.6 & 2.3 & 6.2 & 14.2 \\
\hline Annual household income $(£ 000)$ & 30.8 & 17.6 & 28.3 & 47.7 & 35.0 & 16.9 & 28.6 & 50.1 \\
\hline Annual eq. hh income ( $£ 000)$ & 23.1 & 11.2 & 20.6 & 38.5 & 26.5 & 11.1 & 20.2 & 40.1 \\
\hline Share of hh income (proportion) & 0.36 & 0.40 & 0.33 & 0.35 & 0.31 & 0.30 & 0.29 & 0.33 \\
\hline Home owner* & 0.71 & 0.42 & 0.80 & 0.90 & 0.78 & 0.54 & 0.81 & 0.89 \\
\hline Number of observations & 368 & 121 & 133 & 114 & 28478 & 6139 & 10559 & 11780 \\
\hline Proportion & & 0.33 & 0.36 & 0.31 & & 0.22 & 0.37 & 0.41 \\
\hline
\end{tabular}


* indicates the variable is equal to one if characteristic is true, and so the columns report that characteristic. High education denotes having "A levels" or a higher qualification. couples" sample includes anyone who is married and so is the sample of those who could potentially be in the divorcing sample: the "All married couples" sample is drawn from the original England and Wales BHPS samples, aged between 20 and 60, providing three previous years of household income to allow for assignment to income tercile in the same way as the divorcing sample used for analysis in this paper. The "Divorcing Sample" is a subset of the "All married couples" sample.

At the population level, married couples are not uniformly distributed across the household income distribution: around $41 \%$ of married couples have income in the highest household income tercile, and only $22 \%$ are in the lowest income tercile. Compared to the population level, we have proportionally more observations of divorce from married couples in the lowest income tercile, and not as many observations from the highest income group as would be expected if divorced couples were randomly drawn from the population of married couples. This reflects the known pattern of lower income couples being more likely to divorce (Kiernan and Mueller 1998).

\subsection{Measuring Household Living Standards}

When a marriage dissolves and two new households are formed, the income of each new household will be less than the total before the divorce. This fall in absolute household income is not on its own informative about the fall in living standards that different house- holds experience on divorce for several reasons. First, household size changes after divorce: smaller households need to incur less expenditure than larger ones to reach a given standard of living, although the reduction in income required to achieve the same standard of living is not proportional. Second, living standards are determined by assets as well as income, with housing in particular being a key determinant. Finally, the financial situation that a divorced man or woman find themselves in is not the only determinant of their wellbeing.

To deal with the first limitation of using a measure of absolute income, we calculate equivalised household income by adjusting for household size and composition. To get from absolute to equivalised household income, we divide absolute income by the normalising factor: a large household will have a normalising factor above one and has a lower equivalised income than absolute income, reflecting their higher income requirement to achieve the same standard of living as a two-adult household; whilst a single person household will have a normalising factor below one, increasing their 
equivalised income above absolute income to reflect the higher standard of living achieved with the same absolute income. We can then interpret equivalised income as one measure of the household's standard of living.

Our calculation of equivalised income uses the McClement's (before housing) equivalence scale. ${ }^{9}$ This assigns a normalising factor based on household composition, with a two-adult household without children being the reference unit. A single person household is assigned a value of 0.61 , reflecting that more than half of the resources of a couple household are required to achieve the same standard of living. Each child in the household adds from 0.09 to 0.36 to the household's normalising factor depending on the age of the child, and additional adults add between 0.36 and 0.46 .10

To gain some insight into the effects of differences in assets, we examine changes in housing and living arrangements to the extent allowed by the data. We also look at responses to the General Health Questionnaire (GHQ), which gives a measure of psychological wellbeing to complement our analysis of the financial consequences of divorce.

However, despite examining the available data to evaluate these different dimensions of wellbeing, there remain limitations to our analysis. A primary concern with interpreting changes in equivalised income is the implicit assumption that we can assign a standard of living to the entire household: all resources are shared between all members of the household. We cannot identify whether or not this is the case from our data. We return to this issue in section 4.1.1. In addition, we are limited in the time period post-divorce by our data: there may be longer term benefits or costs that we do not observe.

\footnotetext{
${ }^{9}$ The McClement's equivalence scale has been used in UK government publications such as the Households Below Average Income statistics (Department for Work and Pensions 2015). Since 2005, the modified OECD scale has been used, which tends to assume higher costs for young children and lower costs for additional adults than the McClement's scale. The distribution of equivalised household income is sensitive to the equivalence scale produced; however, the qualitative results presented below are not affected if we instead use the modified OECD scale. We use the before housing equivalence scale, but subtracting reported housing costs and using the after housing equivalence scale makes very little difference to the results presented below.

${ }^{10}$ Weights are as follows for adults: Head 0.61 ; Spouse 0.39 ; other second adult 0.46 ; third adult 0.42 ; further adults 0.36 . For children, weights depend on age: $0-10.09 ; 2-40.18 ; 5-70.21 ; 8-100.23 ; 11-12$ $0.25 ; 13-150.27 ; 16+0.36$.
} 


\section{Changes in Household Resources on Divorce}

This section shows the extent of income losses and access to housing that occur on divorce, and shows how these differ for men and women. Our main focus is to explore the differences in outcomes across the income distribution. The next section considers how these losses are mitigated over time for different groups. The Figures should be interpreted as descriptions of the average actual experience of divorcing men and women.

\subsection{Absolute and Equivalised Income}

Figure 1 plots average income around the time of divorce for men and women: the first point (at time -1) is average income in the last period before divorce occurs, with average income levels from the year immediately following divorce (time 0 ) to the sixth year after divorce (time 5) also plotted. ${ }^{11}$ Absolute income is shown on the left-hand graph and equivalised income on the right-hand graph. Solid lines show changes for women, dashed lines changes for men.

\section{Figure 1: Changes in Absolute and Equivalised Income on Divorce}
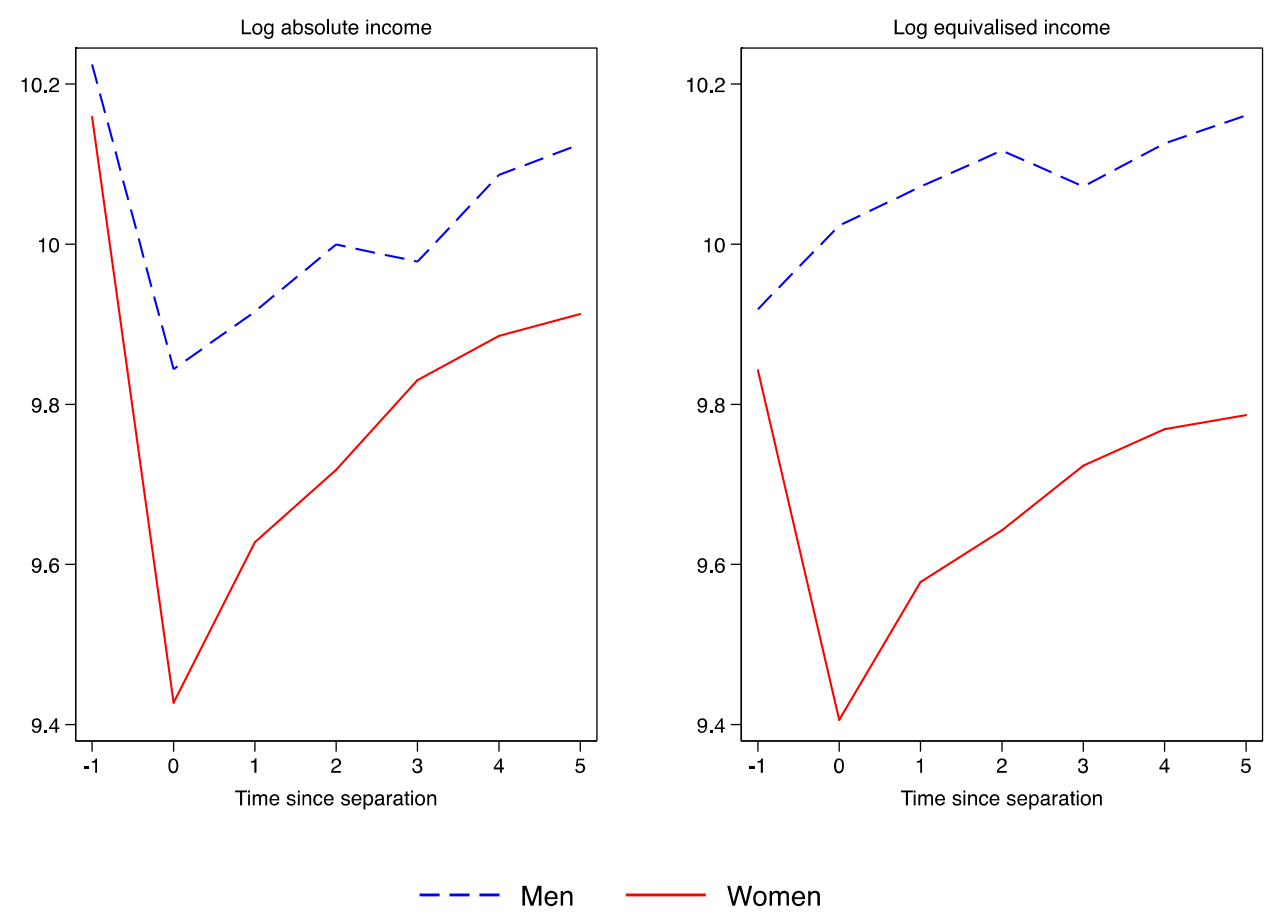

Women

\footnotetext{
11 If, instead, the average household income in the three years prior to divorce is used at $t=-1$, the graphs do not change substantially.
} 
The graphs report the average of log absolute income and the average of log equivalised income. Natural logarithms are used so that the vertical difference between any two points measures the proportional change in income, rather than the monetary change. A fall of 0.4 is approximately a $40 \%$ decline.

Women experience larger falls in absolute income following divorce, but the striking difference is when we look at equivalised income: for men, equivalised income rises on divorce because children more frequently remain with their mothers and so household size falls. The second point shown in Figure 1 is the recovery in income that both men and women experience over time after divorce. However, even 5 years after divorce, there are still substantial differences between men and women.

Since Figure 1 plots averages across all individuals, it hides differences across individuals in the extent of their losses on divorce. To examine these differences, we split the sample into thirds as discussed in section 2. Figure 2 reports the changes in equivalised income for each of the three income groups. The left-hand side reports average changes for women within each income group, the right hand side reports average changes for men within each income group.

The first point to stress is that across the distribution, men have higher equivalised income after divorce than women. All three groups of women experience falls in equivalised income, but differ in terms of magnitude and recovery: the highest income group fall furthest and recover least, consistent with the findings of Brewer and Nandi (2014). The lowest income group have completely recovered their standard of living within 3 years.

Among men, the increase in equivalised income that we observe on average is being driven by an increase for the lowest income group. This is partly driven by differences in the number of children across the distribution: Table 1 shows that the lowest income men have the most children and so their equivalised income increases most when their children no longer live with them.

This highlights the potential importance of the number of children in the household. The bottom row of Figure 2 splits the sample of women into those with resident children at the time of divorce and those without. Equivalised income falls by more for those women with children, but it is striking that all groups of women experience some fall. 
Brewer and Nandi (2014) show that in raw figures, the women who lose most are those women whose children have left home, who are older and potentially retired. ${ }^{12}$

One concern with interpreting Figures 1 and 2 is that observable (and unobservable) differences in individual characteristics between individuals who leave the sample and those who stay in the sample for longer could explain the income trends between men and women, and between the income groups. For example, if people who experience a persistent large fall in household income are more likely to drop out of the survey, these bad outcomes would be removed from our sample as time since divorce increases. This would create the appearance of the recovery of household income that does not reflect the average experience of our sample. In addition, if household incomes are increasing on average in general, then this time trend could obscure the changes in income resulting from divorce, reducing the perceived impact of divorce and overestimating recovery. We use regression analysis in Table 2 to disentangle these effects and to perform statistical tests for differences in income changes between genders and income groups.

Our regressions use data for our selected sample only; that is for our sample of people who are observed to become divorced at some point. We do this as there may be unobservable differences between people who divorce and people who do not divorce which means that the trend in household income for intact couples does not provide a good estimate of the underlying trend in household income for our divorcing sample. Instead, our approach uses the trend in household income for individuals who will divorce in future, or have divorced in the past, to control for the underlying trend in household incomes at the time of divorce.

12 The group of women without dependent children at the time of divorce in our sample includes women from childless marriages, as well as women whose children have already left home. As discussed in Brewer and Nandi, there are likely to be differences across these two sub-groups. 
Figure 2: Changes in Equivalised Income on Divorce by Income Tercile
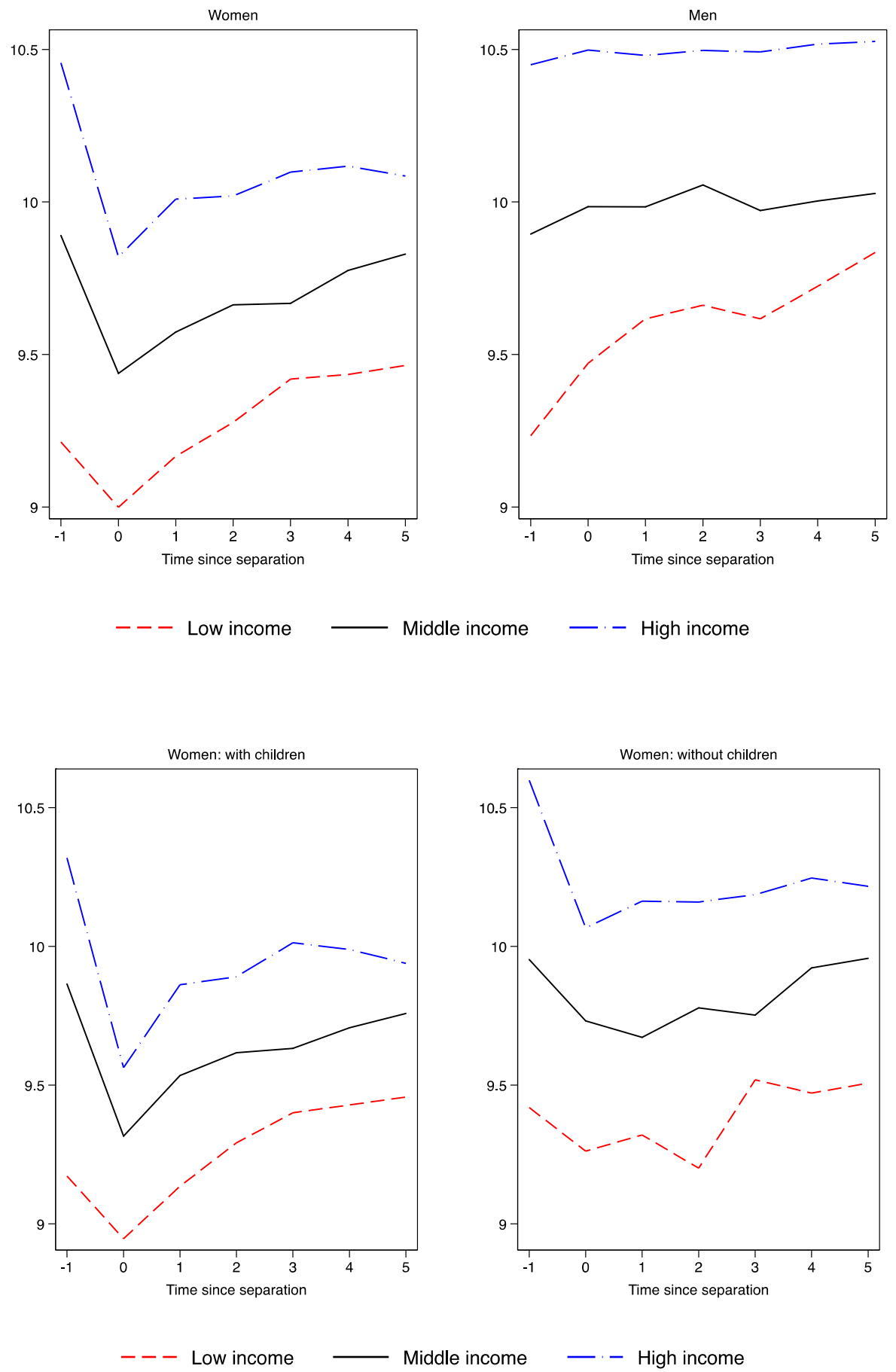

The graphs report the average of log equivalised income. Natural logarithms are used so that the vertical difference between any two points measures the proportional change in income, rather than the monetary change. A fall of 0.4 is approximately a $40 \%$ decline. The top row reports changes for women on the lefthand graph and for men on the right-hand graph. The bottom row splits the sample of women into those with dependent children at the time of divorce on the left-hand graph and those without dependent children at the time of divorce on the right-hand graph. 


\section{Regression Formula}

We present results from fixed effect regressions: this looks at variation for each individual over time, and so controls for time-invariant (observable and unobservable) characteristics of individuals. We are estimating the average across households of the change in household income, rather than the change in the average of household income. Our control variables are indicators for the time around the occurrence of divorce. We first estimate the following equation separately for men and for women, and report the results in Columns (1) and (5) of Table 2:

$$
\begin{gathered}
\ln (\text { eq. income })_{i y}^{g}=\beta_{0}^{g} I(t=0)+\beta_{1}^{g} I(t=1)+\beta_{2}^{g} I(t=2)+\beta_{3}^{g} I(t=3)+\beta_{>3}^{g} I(t>3) \\
+\gamma_{y}^{g}+\alpha_{i}^{g}+\varepsilon_{i y}^{g}
\end{gathered}
$$

where we have observations of income for individual $i$ of gender $g$ in year $y$. A series of binary variables indicate the years after relationship breakdown: $I(t=n)$ is an indicator for year $n$ after divorce, where $n$ is $0,1,2,3$ or $>3$. The set of $\beta_{n}{ }^{g}$ coefficients are the estimates of interest. The omitted category is the pre-divorce period of at least three and up to five years, so these $\beta_{n}{ }^{g}$ coefficients estimates the average difference $n$ years after divorce compared to the average pre-divorce household income for gender $g$. We also include $\gamma_{y}$, a set of year fixed effects capturing underlying time trends in household income; $\alpha_{i}$, a set of individual fixed effects which captures all time-invariant characteristics (including pre- divorce characteristics); and $\varepsilon_{i y}$ is an individual and year specific error term. We expand this regression equation in Columns $(2,3,4)$ and $(6,7,8)$ of Table 2 by including interactions between the set of time since divorce indicators and income group.

By estimating these equations using a fixed effects approach, we control for all individual characteristics that are constant over time, including those that are unobserved. For example, by doing this, we have controlled for whether the individual had a dependent child at the time of divorce because this is a fixed characteristic. We therefore obtain estimates of the average effect for the group. ${ }^{13}$ There are, however,

\footnotetext{
13 This approach also means that even if attrition from the sample were caused by particularly bad income outcomes on divorce, this would not explain the recovery that we estimate because identification is from changes for given individuals.
} 
limitations to this approach: we are estimating the impact of divorce on household income for those who divorce. We are not able to forecast the likely impact of divorce for those individuals who did not divorce, and we cannot draw inferences about the impact of divorce in a different time period.

\section{Results}

Regression results are reported in Table 2 . The estimated coefficients are the average of the difference in log equivalised household income between the time after divorce and the pre-divorce period. This approximates the percentage change in equivalised household in- come compared to the pre-divorce period. For example, in column 1 of Table 2, women's equivalised household income falls by around 48\% immediately following divorce relative to average income in the five years preceding divorce, whilst men's equivalised household income increases on average by $8 \%$.

Table 2: Regression Results: Equivalised Household Income

\begin{tabular}{|c|c|c|c|c|c|c|c|c|}
\hline & \multicolumn{4}{|c|}{ Men } & \multicolumn{4}{|c|}{ Women } \\
\hline & $\begin{array}{l}\text { (1) } \\
\text { All } \\
\end{array}$ & $\begin{array}{c}\text { (2) } \\
\text { Low } \\
\text { Income }\end{array}$ & $\begin{array}{c}\text { (3) } \\
\text { Middle } \\
\text { Income }\end{array}$ & $\begin{array}{c}(4) \\
\text { High } \\
\text { Income }\end{array}$ & $\begin{array}{l}(5) \\
\text { All } \\
\end{array}$ & $\begin{array}{c}(6) \\
\text { Low } \\
\text { Income }\end{array}$ & $\begin{array}{c}\text { (7) } \\
\text { Middle } \\
\text { Income }\end{array}$ & $\begin{array}{c}\text { (8) } \\
\text { High } \\
\text { Income }\end{array}$ \\
\hline \multicolumn{9}{|c|}{ Time since divorce } \\
\hline \multicolumn{9}{|c|}{ Omitted category: up to five years pre-divorce } \\
\hline$t=0$ & $\begin{array}{c}\mathbf{0 . 0 8 1} \\
(0.039)\end{array}$ & $\begin{array}{c}\mathbf{0 . 1 6 9} \\
(0.076)\end{array}$ & $\begin{array}{c}0.062 \\
(0.070)\end{array}$ & $\begin{array}{c}0.021 \\
(0.052)\end{array}$ & $\begin{array}{r}-\mathbf{0 . 4 7 6} \\
(0.040)\end{array}$ & $\begin{array}{l}\mathbf{- 0 . 2 8 7} \\
(0.063)\end{array}$ & $\begin{array}{l}-\mathbf{0 . 4 8 9} \\
(0.063)\end{array}$ & $\begin{array}{c}\mathbf{- 0 . 6 8 3} \\
(0.072)\end{array}$ \\
\hline$t=1$ & $\begin{array}{c}0.075 \\
(0.044)\end{array}$ & $\begin{array}{c}\mathbf{0 . 2 6 9} \\
(0.075)\end{array}$ & $\begin{array}{c}0.021 \\
(0.084)\end{array}$ & $\begin{array}{l}-0.030 \\
(0.050)\end{array}$ & $\begin{array}{c}\mathbf{- 0 . 3 4 2} \\
(0.041)\end{array}$ & $\begin{array}{c}\mathbf{- 0 . 1 6 7} \\
(0.071)\end{array}$ & $\begin{array}{c}-\mathbf{0 . 3 7 7} \\
(0.059)\end{array}$ & $\begin{array}{c}\mathbf{- 0 . 5 1 0} \\
(0.062)\end{array}$ \\
\hline$t=2$ & $\begin{array}{c}\mathbf{0 . 0 9 6} \\
(0.045)\end{array}$ & $\begin{array}{c}\mathbf{0 . 2 9 5} \\
(0.086)\end{array}$ & $\begin{array}{c}0.065 \\
(0.058)\end{array}$ & $\begin{array}{c}-0.036 \\
(0.062)\end{array}$ & $\begin{array}{c}-\mathbf{0 . 2 8 6} \\
(0.044)\end{array}$ & $\begin{array}{c}-0.068 \\
(0.069)\end{array}$ & $\begin{array}{c}\mathbf{- 0 . 3 1 1} \\
(0.054)\end{array}$ & $\begin{array}{c}\mathbf{- 0 . 5 1 5} \\
(0.077)\end{array}$ \\
\hline$t=3$ & $\begin{array}{c}0.009 \\
(0.073)\end{array}$ & $\begin{array}{c}0.179 \\
(0.207)\end{array}$ & $\begin{array}{c}-0.057 \\
(0.064)\end{array}$ & $\begin{array}{c}-0.068 \\
(0.066)\end{array}$ & $\begin{array}{c}-\mathbf{0 . 2 4 9} \\
(0.051)\end{array}$ & $\begin{array}{c}0.024 \\
(0.067)\end{array}$ & $\begin{array}{c}\mathbf{- 0 . 3 2 8} \\
(0.066)\end{array}$ & $\begin{array}{r}\mathbf{- 0 . 4 7 3} \\
(0.092)\end{array}$ \\
\hline$t>3$ & $\begin{array}{c}0.014 \\
(0.055)\end{array}$ & $\begin{array}{c}\mathbf{0 . 2 7 7} \\
(0.090)\end{array}$ & $\begin{array}{c}-0.053 \\
(0.058)\end{array}$ & $\begin{array}{c}-0.123 \\
(0.069)\end{array}$ & $\begin{array}{c}\mathbf{- 0 . 2 0 3} \\
(0.051)\end{array}$ & $\begin{array}{c}0.084 \\
(0.063)\end{array}$ & $\begin{array}{c}-\mathbf{0 . 2 2 0} \\
(0.059)\end{array}$ & $\begin{array}{c}\mathbf{- 0 . 5 0 4} \\
(0.072)\end{array}$ \\
\hline Observations & 3073 & 817 & 1107 & 1149 & 4267 & 1419 & 1480 & 1368 \\
\hline Individuals & 273 & 74 & 99 & 100 & 368 & 121 & 133 & 114 \\
\hline
\end{tabular}

The dependent variable is log equivalised household income. Logs are used so that coefficients can be interpreted as proportional changes. Regressions include a full set of year indicators to control for underlying trends in household income. Columns 1 and 5, and columns 2-4 and 6-8, are jointly estimated. Robust standard errors clustered by individual in parentheses. Bold indicates significance at 5\% level. 
These results support the conclusions described graphically above: men's increase in equivalised income is only present amongst the lowest income men. All groups of women experience a decrease in household income, and the fall is larger for women from higher income households. The lowest income women recover their household income to pre-divorce levels shortly after relationship breakdown, but the income fall is much more persistent for women from higher income households: women from the highest pre-divorce income tercile have household income $50 \%$ lower than pre-divorce even four years later.

\subsection{Accounting for Housing}

Differences in income do not provide the whole picture of living standards partly because of differences in housing. If men end up with lower quality housing after divorce, then they may be worse off despite having a larger equivalised income. ${ }^{14}$ Further, moving out of home ownership could have long-term impacts that are not captured in equivalised income.

To explore these differences in access to housing, we begin by showing in Figure 3 the fraction of men and women who report moving home following divorce. ${ }^{15}$ This shows the average experience of the divorcing sample.

Figure 3: Housing: Moved Since Divorce

\footnotetext{
${ }^{14}$ We experiment by subtracting housing costs from income and then equivalise using an equivalisation factor that leaves out housing costs. This gives a measure of living standards once housing is removed. When we do this, the results on the changes in equivalised income for men and for women remain as in our baseline results.

${ }^{15}$ In all cases, the graphical analysis presented and conclusions drawn in the remainder of this paper can be backed up with fixed effects regression analysis comparable to Table 2 . These results are available from the authors on request.
} 


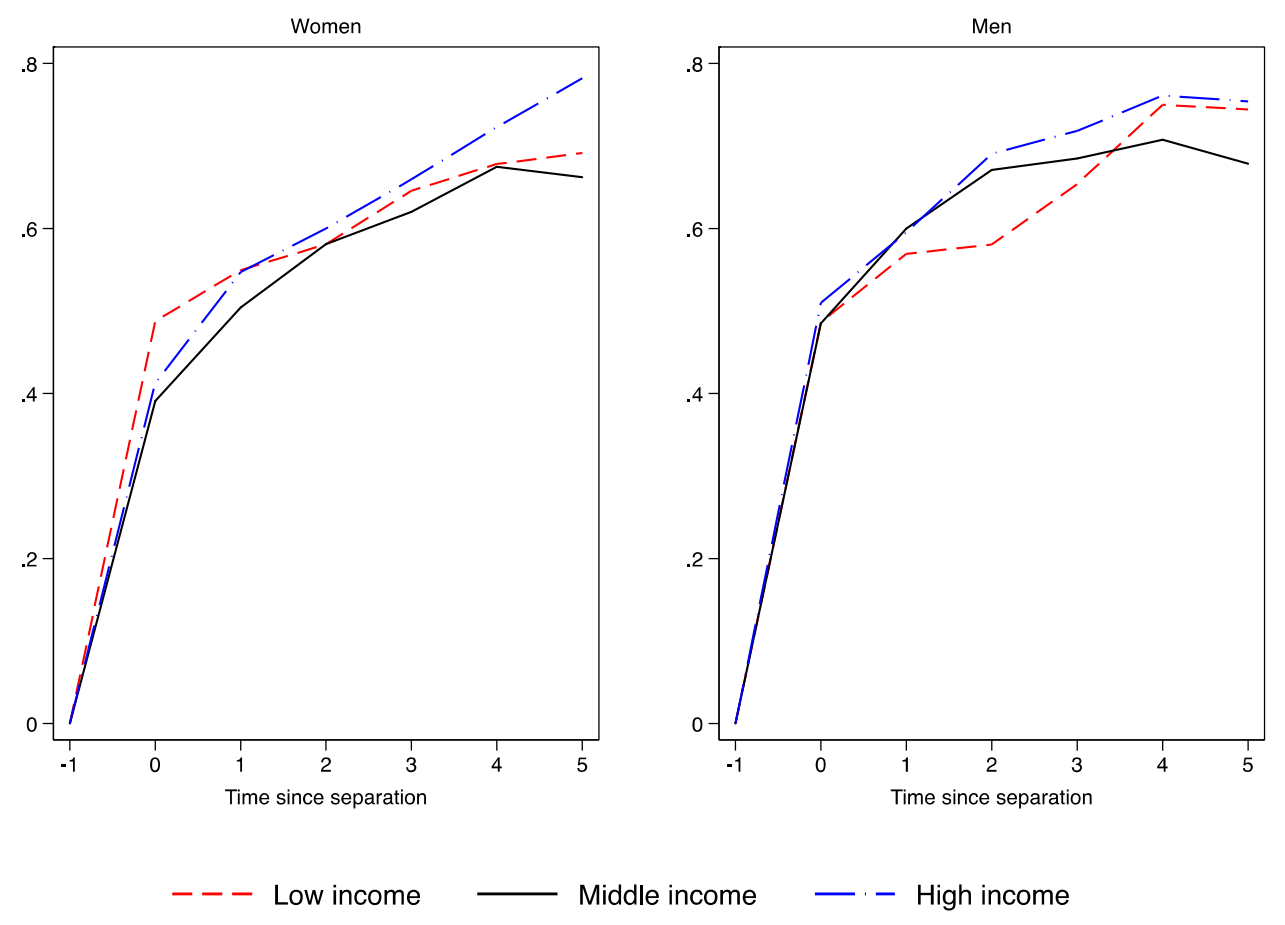

The graphs show the proportions of women (on the left-hand side) and of men (on the right-hand side) who change their home following separation.

In the full sample, there is very little difference between men and women in their probabilities of moving and no differences across the distribution: within 3 years of divorce, $69 \%$ of men and $64 \%$ of women will have moved house. We now examine how this pattern varies by home ownership and by the presence of dependent children at the time of divorce.

Figure 4 shows the proportions of men and women owning, renting and living in social housing, and how this changes over time, also split by the presence of dependent children. Home-ownership falls both for men and for women: men move into rental accommodation, and women move into rental accommodation and social housing. ${ }^{16}$ This symmetry may reflect that marital homes are typically jointly owned. These Figures also show that the presence of dependent children does not change these patterns greatly, with home ownership falling for all groups.

The graphs in the top row of Figure 5 shows how the patterns of home ownership differ across income groups, and the graphs in the bottom row Figure 5 shows how patterns of

\footnotetext{
${ }^{16}$ Evidence from the Netherlands suggests that women are more likely to move out of home ownership after divorce (Feijten 2005; Mulder and Wagner 2010), and the nature of housing tenure changes has been found to be similar across Europe (Dewilde 2008).
} 
renting differ. The fall in ownership rates is lowest among the lowest income men and women who have low ownership rates to start with. Rental rates mirror these findings, spiking up for men and women at divorce, and declining over time.

Figure 6 illustrates the patterns of moving by prior housing tenure, and by the presence of dependent children. Each bar represents the proportion of the pre-divorce housing tenure group who remain in the same house in each of the three years after divorce. The top row of the Figure shows results for all women and for all men. Patterns of staying for home owners are comparable between genders, except in access to social housing: women are far more likely to retain access to their social housing in the years following divorce. This reflects the overall pattern of moving house after divorce observed in Figure 3. 
Figure 4: Housing Tenure After Divorce
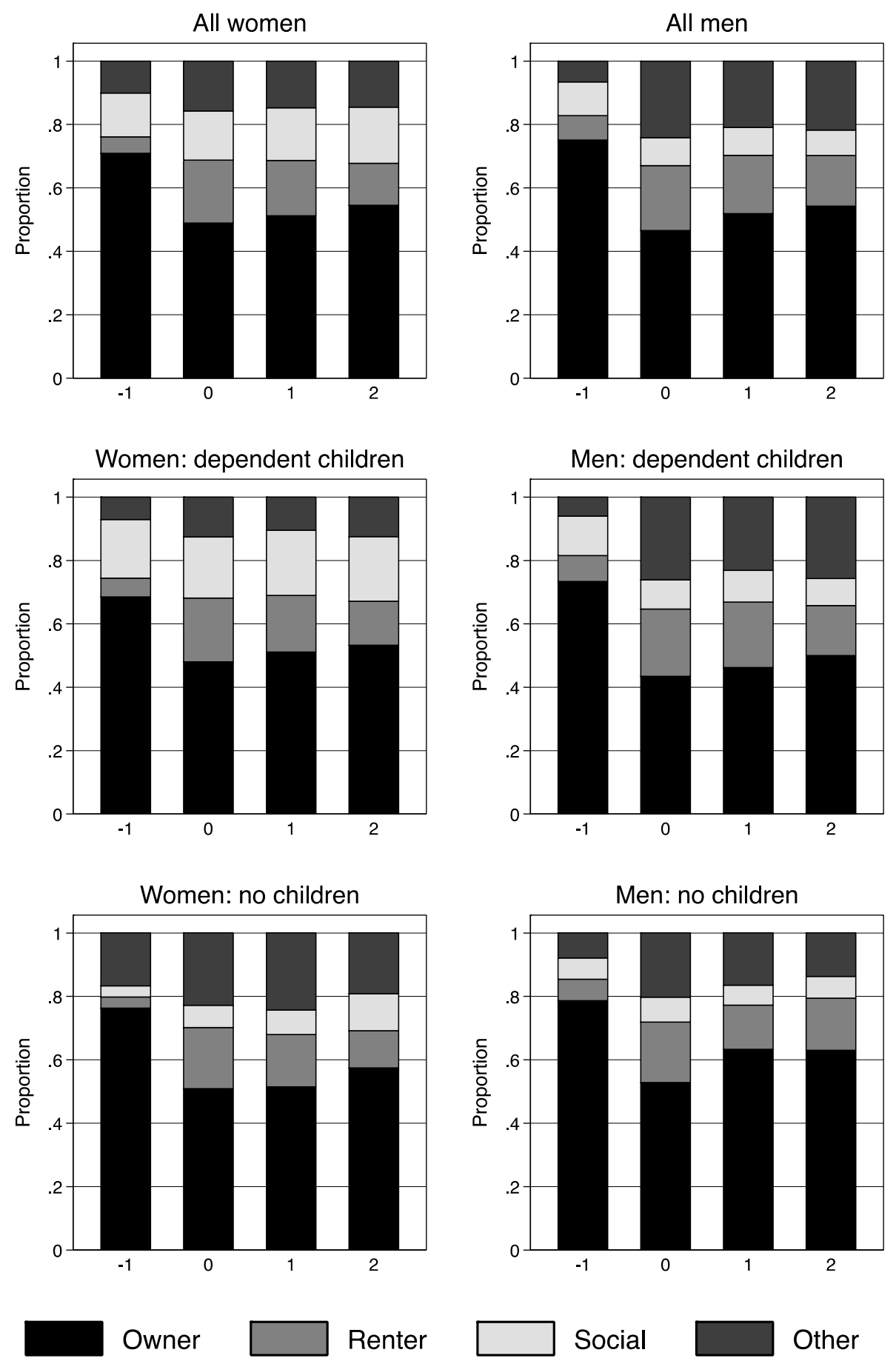

The charts show the proportion of the sample with different housing tenure and how this changes through divorce. The top row shows housing tenure for all women (left-hand chart) and all men (right hand chart). The second row shows tenure for those with dependent children and the bottom row those without dependent children. 
Figure 5: Housing: Ownership and Renting
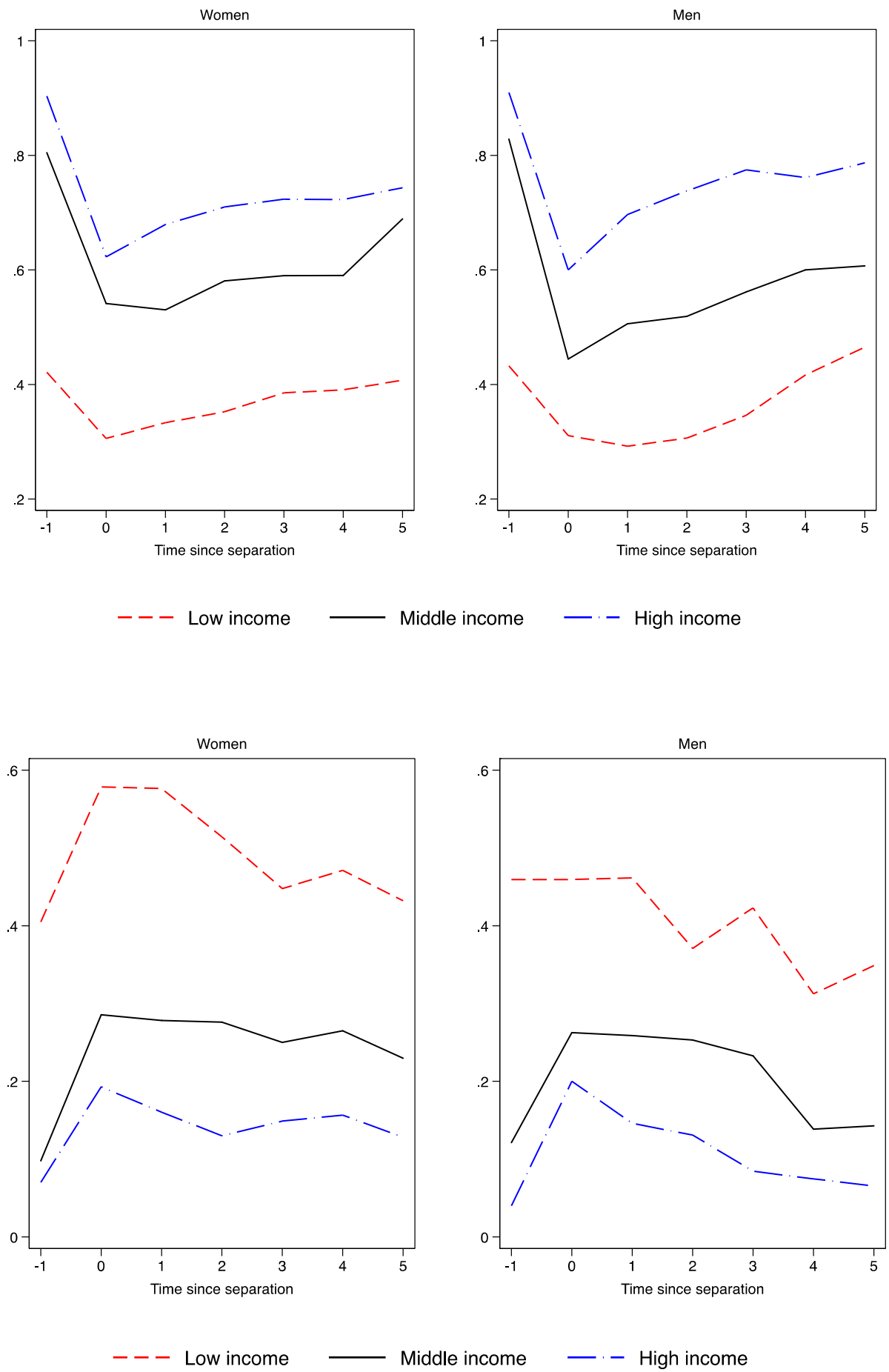

The graphs in the top row show the proportions who own their own home and changes through divorce; the graphs in the bottom row show the proportions who rent their home and the changes through divorce. Proportions for women are on the left-hand side and proportions for men on the right-hand side. 
Figure 6: Proportions staying in the same house after divorce, by initial tenure
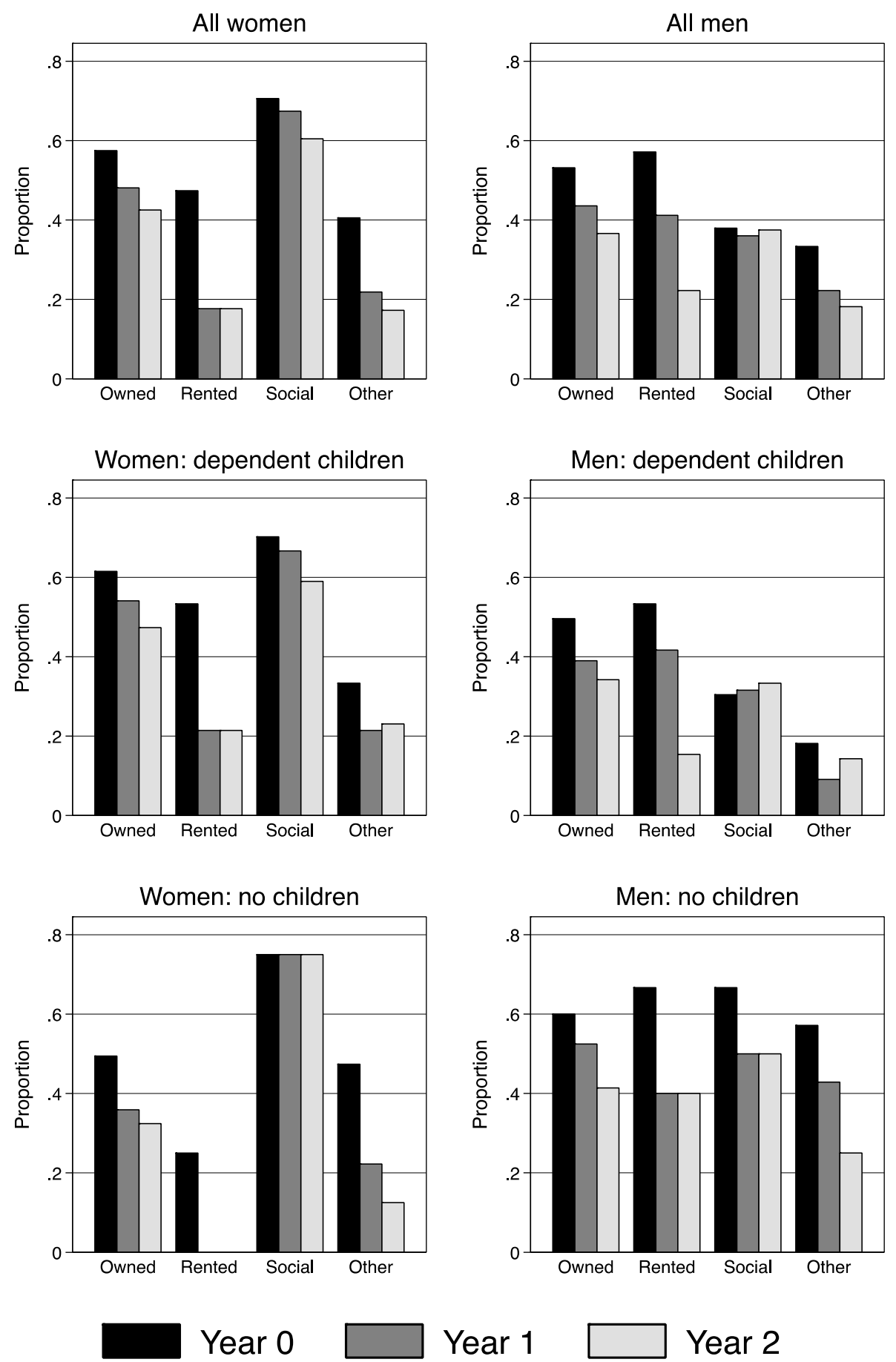

Year 1

Year 2

Each panel shows the proportion of the relevant group still living in the pre-divorce immediately following divorce, and in year 1 and year 2 . Due to sample attrition, in some cases this proportion increases as time since divorce increases, reflecting the attrition of individuals who have already moved out of the marital home. 
Splitting this data by the presence of dependent children reveals a number of additional differences. The middle row shows patterns for women and men with dependent children at the time of divorce: women with children are more likely to stay in their prior residence, with the exception of rented accommodation. This indicates that mothers with dependent children are more likely to retain access to the marital home after divorce. The bottom row shows that among home owners, the opposite is true for divorcing women and men without children at the time of divorce: women are less likely to stay than men, and this is even more true for rented accommodation. The group of couples without dependent children at the time of divorce includes couples who had children who have now left home, raising concerns that older divorcing women may be especially affected by losing access to pre-divorce housing. The pattern of greater access to social housing for women persists regardless of the presence of children.

These results are consistent with those found by Brewer and Nandi (2014), who pool private and social renting and find that women with dependent children are more likely to remain in the family home whether owned or rented.

\section{$4 \quad$ Recovery mechanisms}

Section 3 shows the patterns of living standards and housing over time. The changes in household income and in housing tenure incorporate any steps that individuals have made to mitigate the shocks to their living standards. The aim of this section is to understand what mechanisms act to mitigate the shocks and whether there is differential access to these mechanisms across the income distribution and between men and women. We focus on living arrangements, labour market activity, private transfers and benefit receipt. We present graphical descriptive evidence of the use of these mechanisms, illustrating the average experience within gender and income groups. This means, for example, that the experience is averaged across individuals of different ages, in some figures, averaged across those with and without dependent children at the time of divorce. ${ }^{17}$ Where there are notable differences in experiences between those with and without dependent children at the time of divorce, we present and discuss this additional evidence.

\footnotetext{
17 The conclusions from this graphical analysis are consistent with results from fixed effects regressions comparable to those in Table 2 . These results are available from the authors on request.
} 


\subsection{Living Arrangements}

Individuals choose who they live with after divorce. This may differ in the short- and long- term. For example, some will move in with extended family for short periods of time before transitioning to more permanent arrangements. We distinguish between living with a new partner (either married or unmarried), which is the most common long-term arrangement, and living alone, living with related adults, or living with unrelated adults.

Table 3: Transitions in living arrangements

\begin{tabular}{lccccc}
\hline & $\begin{array}{c}\text { Partner } \\
\%\end{array}$ & $\begin{array}{c}\text { Alone } \\
\%\end{array}$ & $\begin{array}{c}\text { Family } \\
\%\end{array}$ & $\begin{array}{c}\text { Others } \\
\%\end{array}$ & $\begin{array}{c}\text { All } \\
\%\end{array}$ \\
\hline \hline Men & & & & & \\
Year 0 & 13.2 & 68.9 & 11.0 & 7.0 & 100 \\
3 years later: & & & & & \\
$\quad$ Partner & 72.0 & 33.6 & 45.0 & 27.3 & 39.5 \\
$\quad$ Alone & 24.0 & 61.4 & 30.0 & 63.6 & 53.2 \\
$\quad$ Family & 4.0 & 2.9 & 25.0 & 0.0 & 5.2 \\
$\quad$ Others & 0.0 & 2.1 & 0.0 & 9.1 & 2.1 \\
$\quad$ Total & 100 & 100 & 100 & 100 & 100 \\
& & & & & \\
Women & & & & & \\
Year 0 & & & & & \\
3 years later: & 20.5 & 71.6 & 3.3 & 4.6 & 100 \\
$\quad$ Partner & 70.7 & 32.4 & 50.0 & 28.6 & 40.6 \\
$\quad$ Alone & 25.9 & 65.7 & 33.3 & 64.3 & 56.4 \\
$\quad$ Family & 3.5 & 0.5 & 16.7 & 0.0 & 1.6 \\
Others & 0.0 & 1.5 & 0.0 & 7.1 & 1.4 \\
$\quad$ Total & 100 & 100 & 100 & 100 & 100 \\
\hline \hline
\end{tabular}

The Table shows how living arrangements changed between the year immediately after divorce and three years later for men and women. In each panel, the first line shows the proportion of our sample in each living arrangement immediately after divorce. Within these groups, we then show the percentage living either with a partner, alone, with family and with others, three years later. So, for example, of the $68.9 \%$ of men who lived alone immediately following divorce, $33.6 \%$ had repartnered by year 3 .

Table 3 reports the transitions between these alternative living arrangements from living with a spouse prior to divorce to the period immediately after breakdown and to the period three years after breakdown. Immediately after breakdown, around $70 \%$ of men and women live alone. After 3 years, about $40 \%$ of men and women live with new partners, with $16 \%$ of men and $15 \%$ of women remarried. The difference between men 
and women is that women are quicker to repartner, including remarriage and informal cohabitation, but these differences disappear within 3 years. Men are more likely to live with other family or unrelated adults straight after divorce, but this is a temporary state: after 3 years, over $80 \%$ have moved again either to live alone or to live with a new partner. Although the numbers are small, the question of why divorcing women repartner more quickly than divorcing men remains open, but may be due to differential access to the extended family (Fisher and Low, 2015).

These results are in contrast to those found by Brewer and Nandi (2014), who find that men repartner more quickly than women. This difference in results can be explained by our focus on separations from marriage: divorcing men are far slower to repartner than men separating from cohabitation, perhaps reflecting the time taken to complete divorce proceedings.

This Table does not allow us to see differences by the presence or absence of dependent children. Figure 7 illustrates the change in living arrangements after divorce, for all men and women, and broken down by the presence of dependent children.

This reveals a number of insights. First, the 'quick' repartnering amongst women is driven by women without children, although women with dependent children are still more likely to repartner immediately than their former husbands. ${ }^{18}$ By year 3 , any differences in the repartnering rate have disappeared for women, but men without children have continued to repartner more quickly than those with children. In addition, it is men with dependent children who are most likely to rely on living with extended family after divorce, and this is more persistent than for those without children. Women with dependent children are extremely unlikely to rely on family or friends for housing after divorce.

Table 3 also masks some differences across the distribution in living arrangements. These differences are highlighted in Figures 8 and 9.

\footnotetext{
${ }^{18}$ Again, this is in contrast to Brewer and Nandi (2014) who pool separations from marriage and cohabitation.
} 
Figure 7: Living arrangements by presence of children
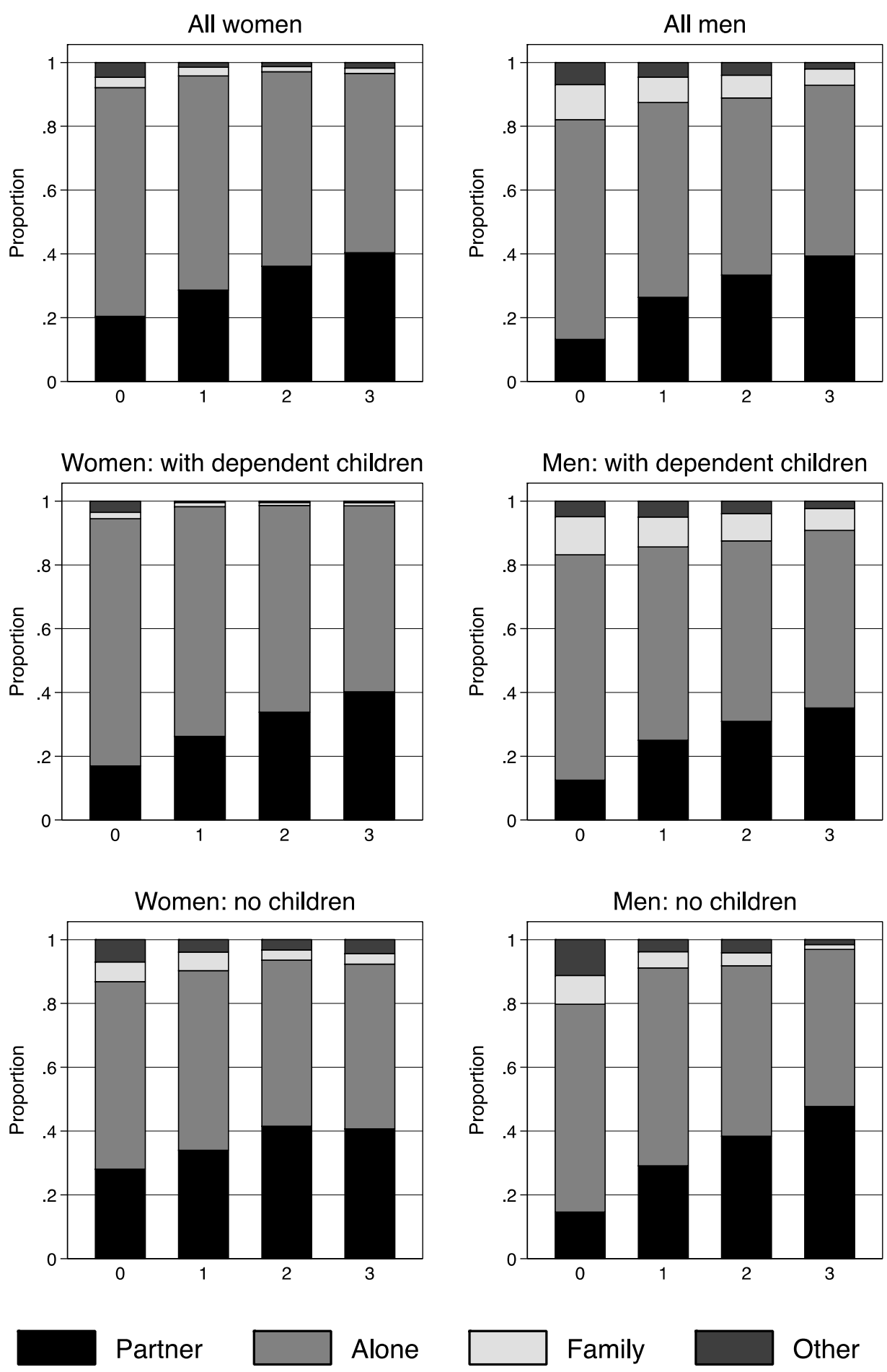

Graphs show how the living arrangements of our divorcing sample changes after divorce, separated out by gender and the presence of dependent children. 
Figure 8: Repartnering

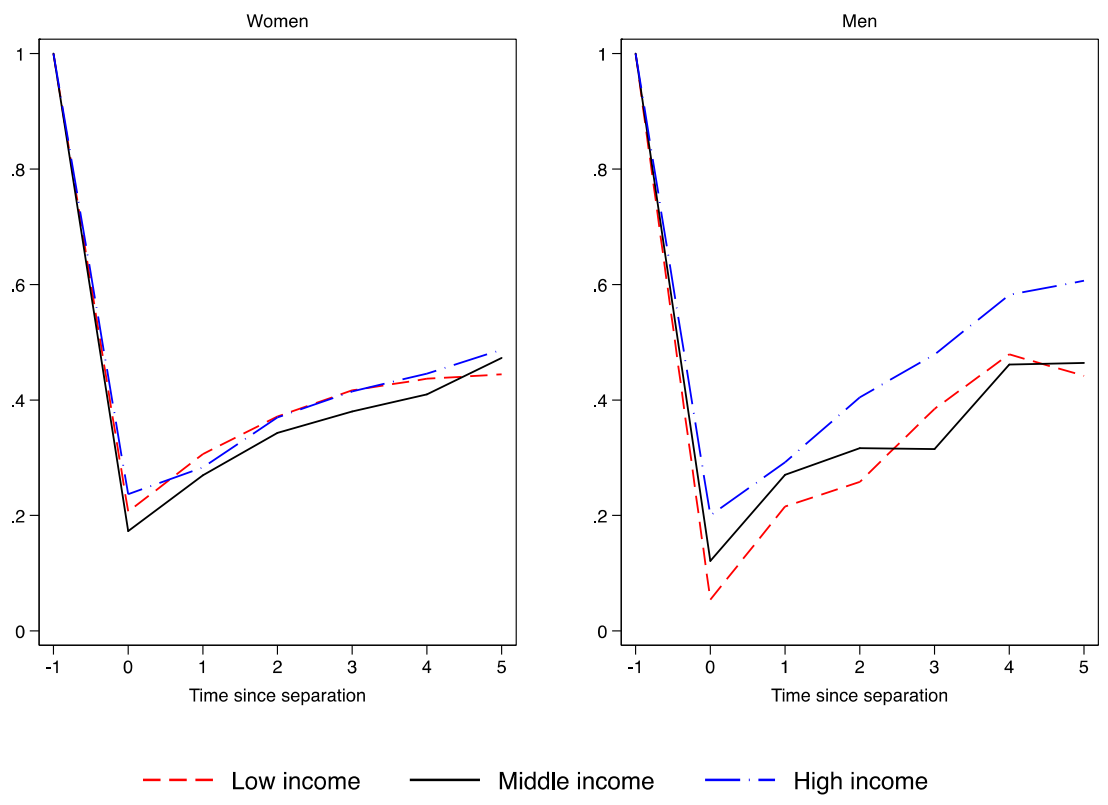

The graphs show the proportions of women and of men who are living as if married.

Figure 9: Living arrangements: extended family

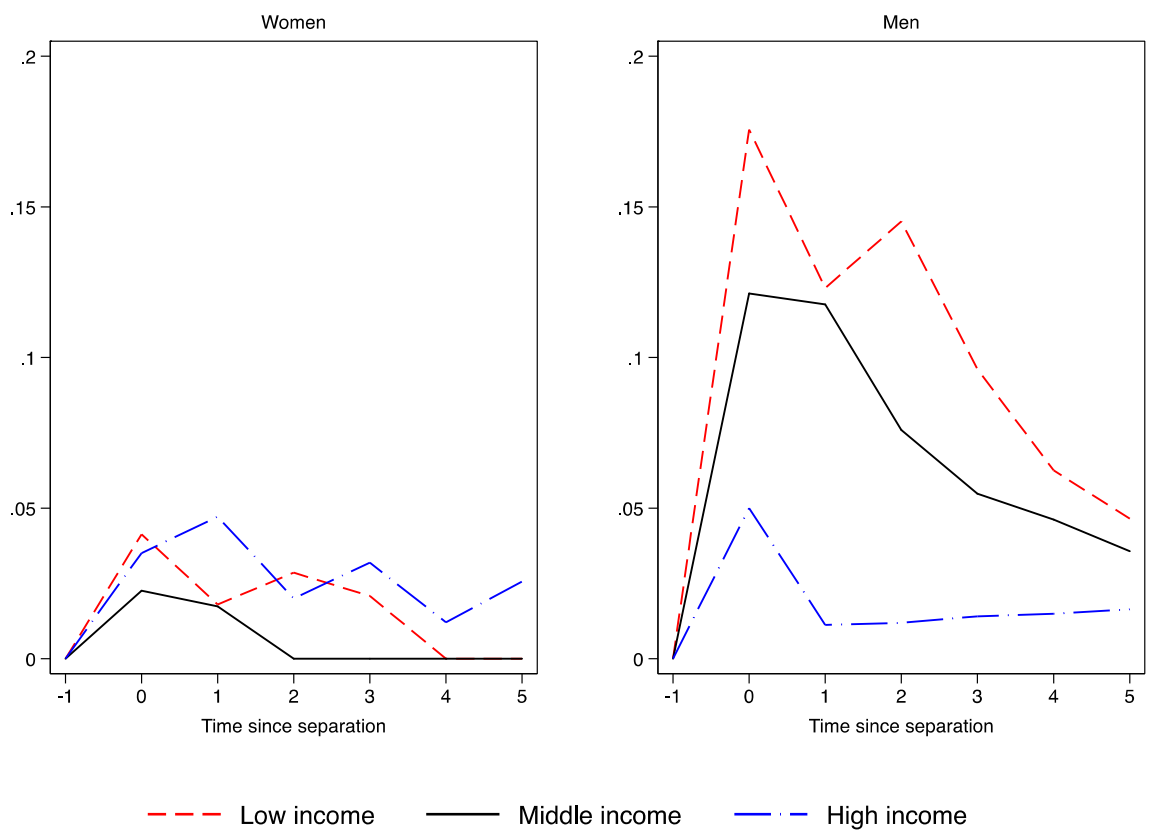

The graphs show the proportions of women and of men who are living with their extended family.

Figure 8 shows the pattern of repartnering including both remarriage and moving in with an unmarried partner. There is little difference in repartnering rates across the 
income distribution for women, whereas higher income men appear to repartner more quickly. Figure 9 shows the pattern of living with related adults (typically parents), with women on the left-hand side and men on the right-hand side. Women are very unlikely to move in with related adults following divorce. Men are much more likely to do so, and this is especially the case among the lowest income men. Fisher and Low (2015) show that this behaviour of married women is in contrast to women who were cohabiting who are much more likely to move in with extended family following separation in a similar way to the men. We also explore differences in living with unrelated adults across the distribution: all groups using this as a temporary arrangement.

\subsubsection{Income sharing}

The analysis above has highlighted the importance of alternative living arrangements in smoothing the income shocks accompanying divorce, particularly for men. In the analysis of changes to income so far, we have assumed there is complete income pooling within households and so there is a common standard of living within the household. However, when an individual lives with people outside of their nuclear family (that is, other than their partner and dependent children) then this assumption of a common standard of living is likely to be misleading. To get some insight into the possible effect of this assumption on the results presented above, we redo the analysis but only consider the income of the nuclear family, not the entire household. We refer to this as 'family income'. ${ }^{19}$ Excluding income from other household members makes little difference to conclusions drawn about the experiences of women or men from the highest income group. In contrast, the pattern of income changes for the low and middle income men changes: the middle income men no longer experience an average increase in equivalised family income, and the speed of increase of the lowest income men's equivalised income is slowed. This is to be expected because it is the lower men who tend to move to live with extended family or unrelated adults. Once the income of these other adults is excluded, the difference in the experiences of men and women in the low and middle income groups is reduced.

These results should be interpreted as a lower bound on the economic impact of divorce on an individual's standard of living, as measured by income (assuming that nuclear

\footnotetext{
${ }^{19}$ We apply the McClements (before housing) equivalence scale for that nuclear family group to define equivalised family income.
} 
families do share a common standard of living). It is likely that, in most cases, a divorcing individual gains some of the benefits of the higher overall household income of a larger household, either through higher quality housing than would otherwise be achieved or through other shared household consumption.

A further consideration in a similar vein is that we have assumed that there is income pooling within a marriage. To the extent that income is not shared, the economic loss of divorce for the lower earner may be less than estimated above.

\subsection{Labour Market}

One potentially important way in which individuals can mitigate income losses on divorce is through changing their labour supply behaviour. Figure 10 shows how employment changes over time and over the distribution and Figure 11 shows how hours of work (for those in work) change over time across the distribution.

\section{Figure 10: In Paid Employment}

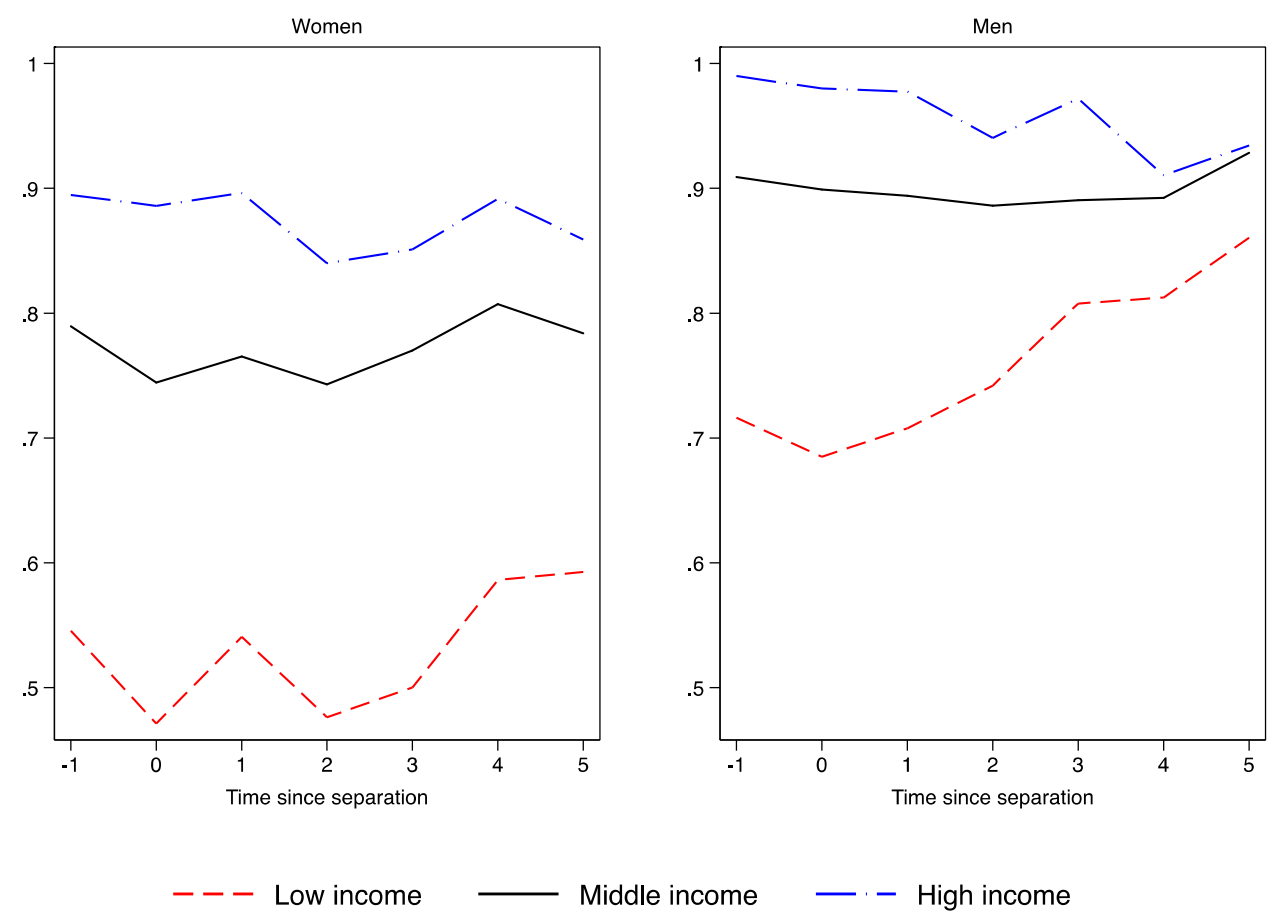

The graphs show the proportions of women and of men who have some level of paid employment.

Overall, there is little change in hours worked or employment after divorce: labour supply responses do not mitigate the income losses. Unreported fixed effects regression 
analysis suggests that there are no statistically significant increases in hours of work or in participation for any group. A closer examination of the data reveals that the visible upward trend in participation amongst low income men is driven entirely by men without dependent children, and does not reach statistical significance. In England and Wales in this time period, divorcing individuals do not respond to divorce by altering their labour market activity.

Figure 11: Hours worked (conditional on working)

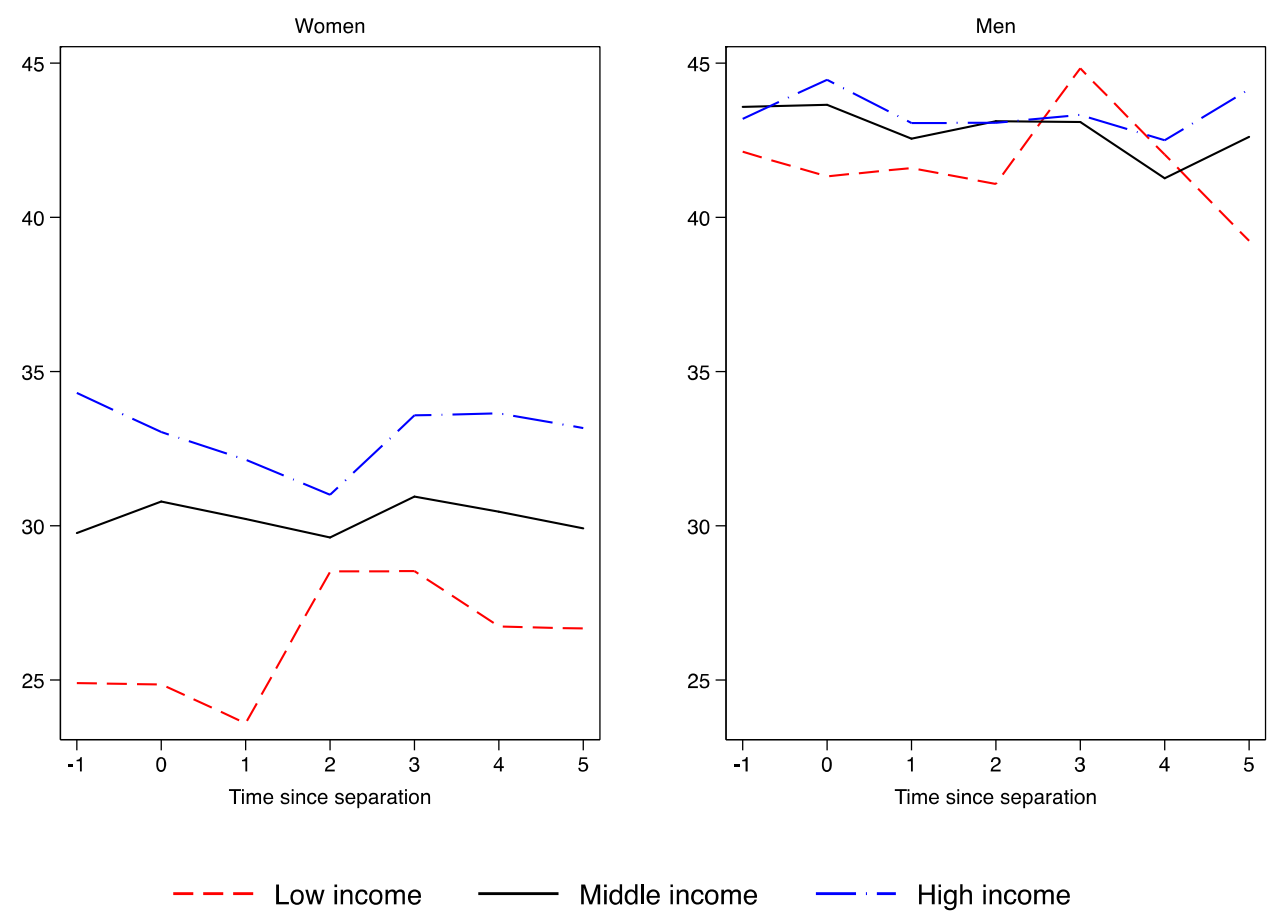

The graphs show average weekly hours worked for women and for men for those who have some level of paid employment.

\subsection{Transfers}

After divorce, transfers can be made for child support and for spousal maintenance and these can help to mitigate losses, especially for women. Our data shows these transfers are rare where a married couple did not have dependent children at the time of divorce: three years after divorce $2.2 \%$ of women without dependent children report receiving transfer income in this category compared to $34 \%$ of women with dependent children. This is consistent with previous work on maintenance transfers in the UK finding 
extremely low rates where a married couple had no children (Eekelaar and Maclean 1986) and the highest prevalence of such transfers amongst married couples with dependent children (Maclean and Eekelaar 1997). For this reason, in this section we present figures based on a restricted sample of divorcing individuals with dependent children at the time of divorce.

\section{Figure 12: Transfers Women Receiving a Transfer; Men Making a Transfer}

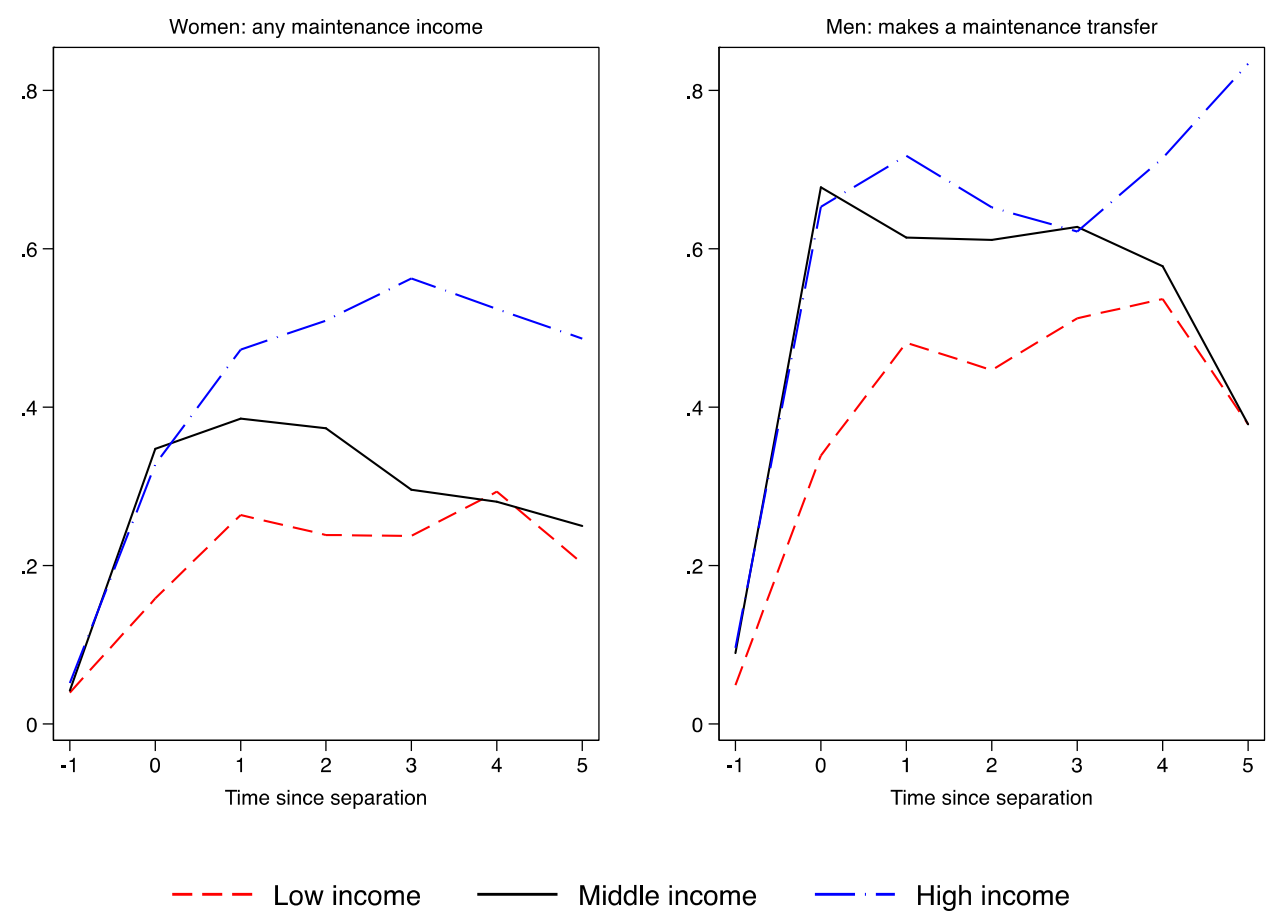

The left graph shows the proportion of women receiving a transfer within each income group; the right graph shows the proportion of men who make a transfer within each income group.

The left-hand side of Figure 12 shows the proportion of women reporting that they receive a maintenance transfer from their former partner; ${ }^{20}$ the right hand side shows the proportion of men who report making such transfers. There are discrepancies here: more transfers are "being made" than are "being received". This may reflect a reporting misclassification of child support or the reality that much of the transfer of child support is being taxed away for much of the time frame. There is some evidence in this Figure

\footnotetext{
20 The BHPS asks about 'alimony and child support' as one income source, so it is not possible to distinguish between administrative child support and court ordered maintenance; we refer to any amount reported as a maintenance transfer.
} 
that lower income women are less likely to receive transfers than the rest: this is consistent with other studies of low income separating women finding low rates of child support receipt (Bryson et al. 2013).

Figure 13 reports further on the transfers received by women with dependent children, with the left-hand side reporting the average amount of income received, and the righthand side the amount received for those who receive a positive amount. Women from the highest income households are more likely to receive a transfer, and those that do receive a transfer receive much more than the rest of the distribution.

Figure 13: Transfers: Average Maintenance Income

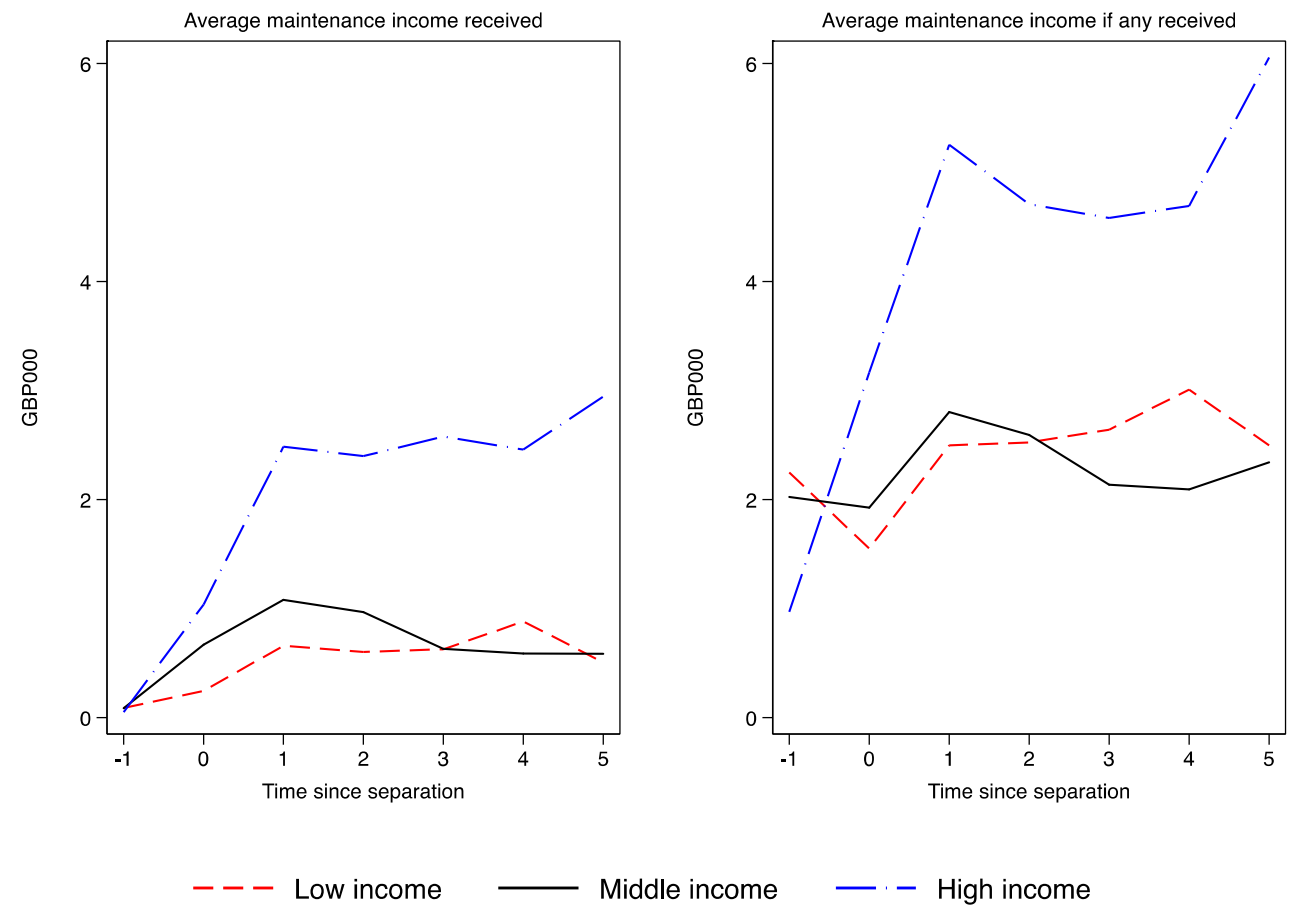

The left-hand side shows average amount received across all women, the right-hand side shows the average amount received among those who receive a positive amount. 


\subsection{Benefits}

In addition to the private mechanisms for mitigating income losses, the state provides sup- port through the benefits system. Figure 14 shows how the amount of household benefit income changes over time and across the distribution. We might expect benefit income to be particularly important for lower income groups in society. Indeed, the lowest income men and women receive the most income through benefits. However, benefit income does not increase as much for the lowest income women as for women from the highest income households. Middle and high income women sustain larger losses on divorce and become more reliant on benefits.

\section{Figure 14: Log Household Benefit Income}

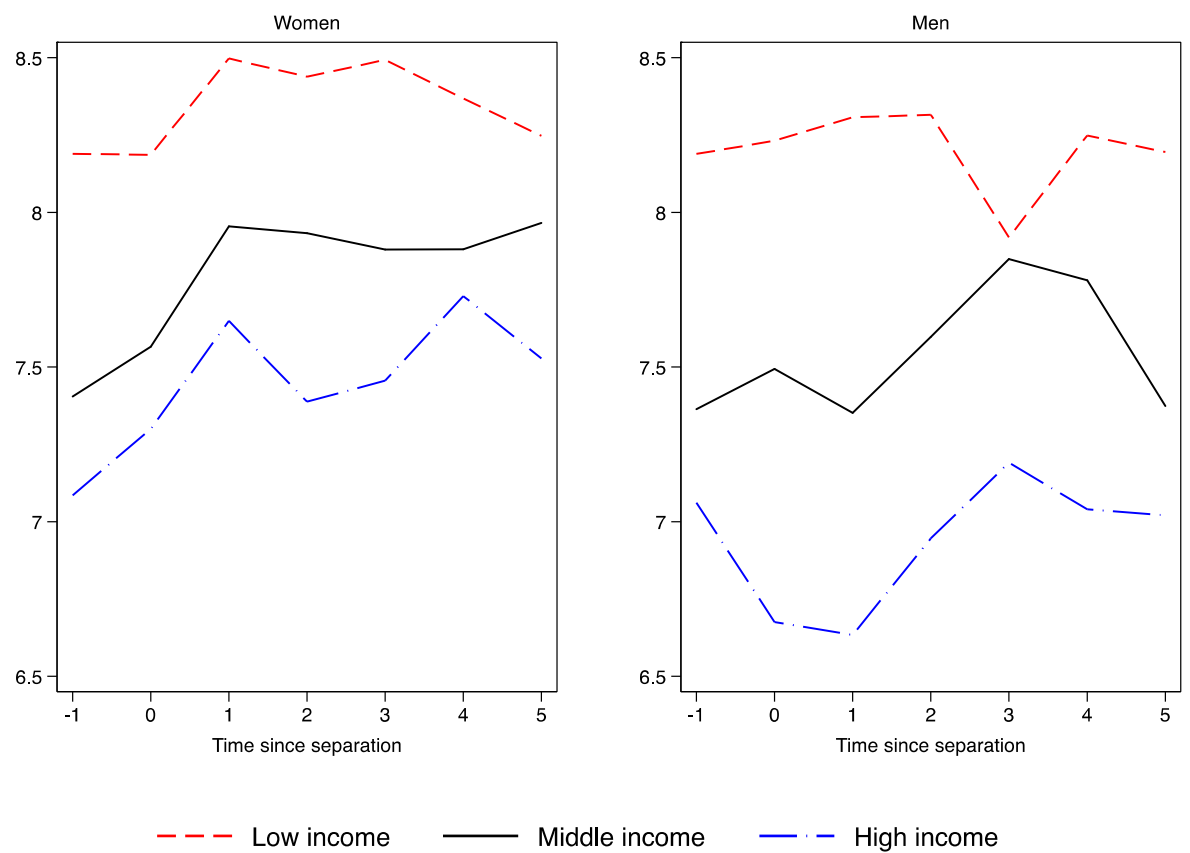

The graphs report the average of log of benefit income. Natural logarithms are used so that the vertical difference between any two points measures the proportional change in income, rather than the monetary change. A rise of 0.4 is approximately a $40 \%$ increase. 


\section{Figure 15: Benefit income}
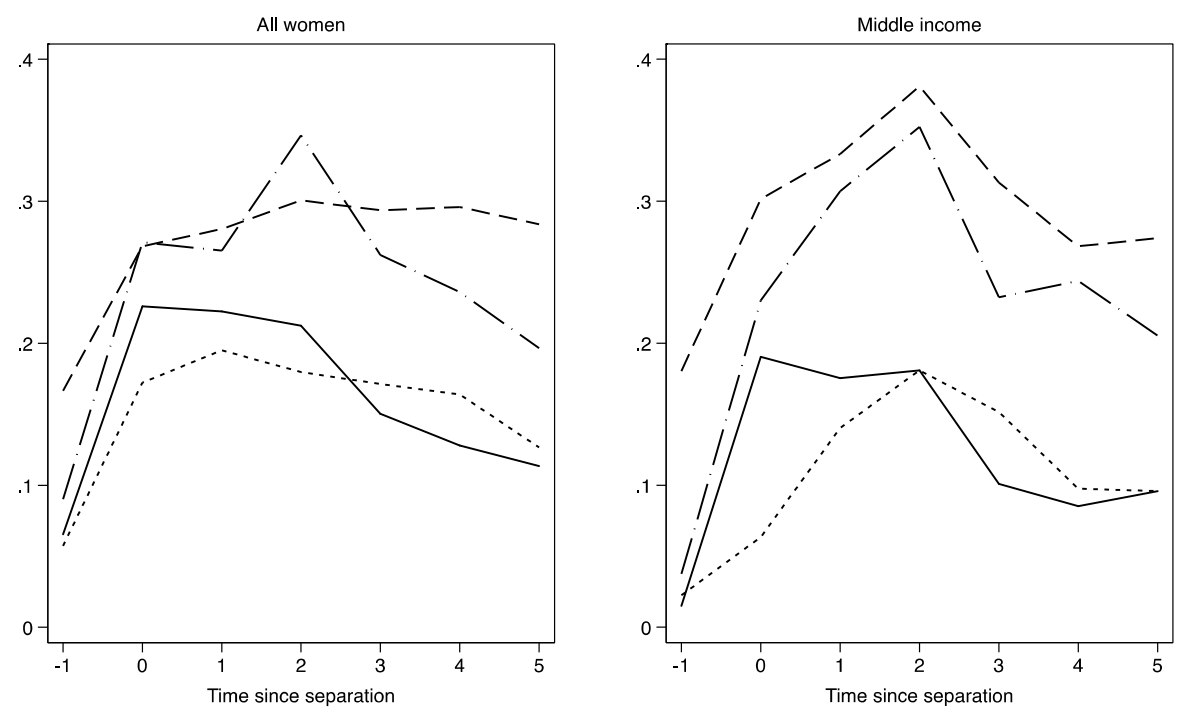

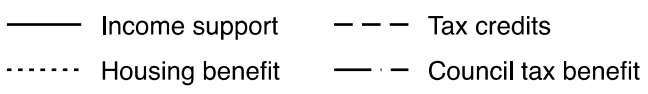

The graphs show the proportions of women who receive each type of benefit income. The left graph shows proportions of all women, the right graph shows the proportions for women in the middle income group.

Figure 15 breaks down the source of benefit income for women into income support, housing benefit, tax credits and council tax benefit. The left-hand graph reports the breakdown for all women, the right-hand graph reports the breakdown for the middle income group who experienced the largest increase. The Figure highlights that all aspects of the benefit system are providing support, but that some of this support takes time to start.

\subsection{Overall Recovery Mechanisms}

The analysis above has shown how income changes around divorce, and how various characteristics and income components change. This section aggregates this information to consider the relative contributions of various income sources to household income. First, graphical analysis shows how the sources of income change over time. ${ }^{21}$ Fixed effects regression analysis then shows the contribution of living arrangements and labour supply to the mitigation of falls in household income.

\footnotetext{
${ }^{21}$ We use absolute measures of household income in this section.
} 
Figure 16 shows average income broken down into its main components. Variation over the time around divorce reflects both changes in the proportion of that group receiving any income, and changes in the average amount received. So, the increase in average partner income from time 0 mostly reflects the process of repartnering rather than a change in the average income of partners.

Figure 16 shows the overall pattern of average household income for women and men around the time of divorce for the three income groups. The bottom row of graphs shows clearly that for men in the highest income group, the reduction in household income results from the removal of his wife's income, with recovery largely resulting from repartnering: men's own private income does not vary. By contrast, in the lowest income group, men increase their private income after divorce, with benefits remaining as important as before separation and income from others playing an important role in smoothing income. Income from others is also important for men in the middle income group.

The top row of graphs shows that, for women, benefit income plays a larger role across the income distribution, and income from others a smaller role. The larger roles of transfer income and repartnering are also visible across the income distribution. The extent to which decisions about labour supply and living arrangements, and the receipt of spousal periodical payments and child support mitigate the fall in household income is examined further in Table 4. This is comparable to Table 2, with the addition of regressors for post-divorce behaviours. 
Figure 16: Composition of Household Income Around Divorce
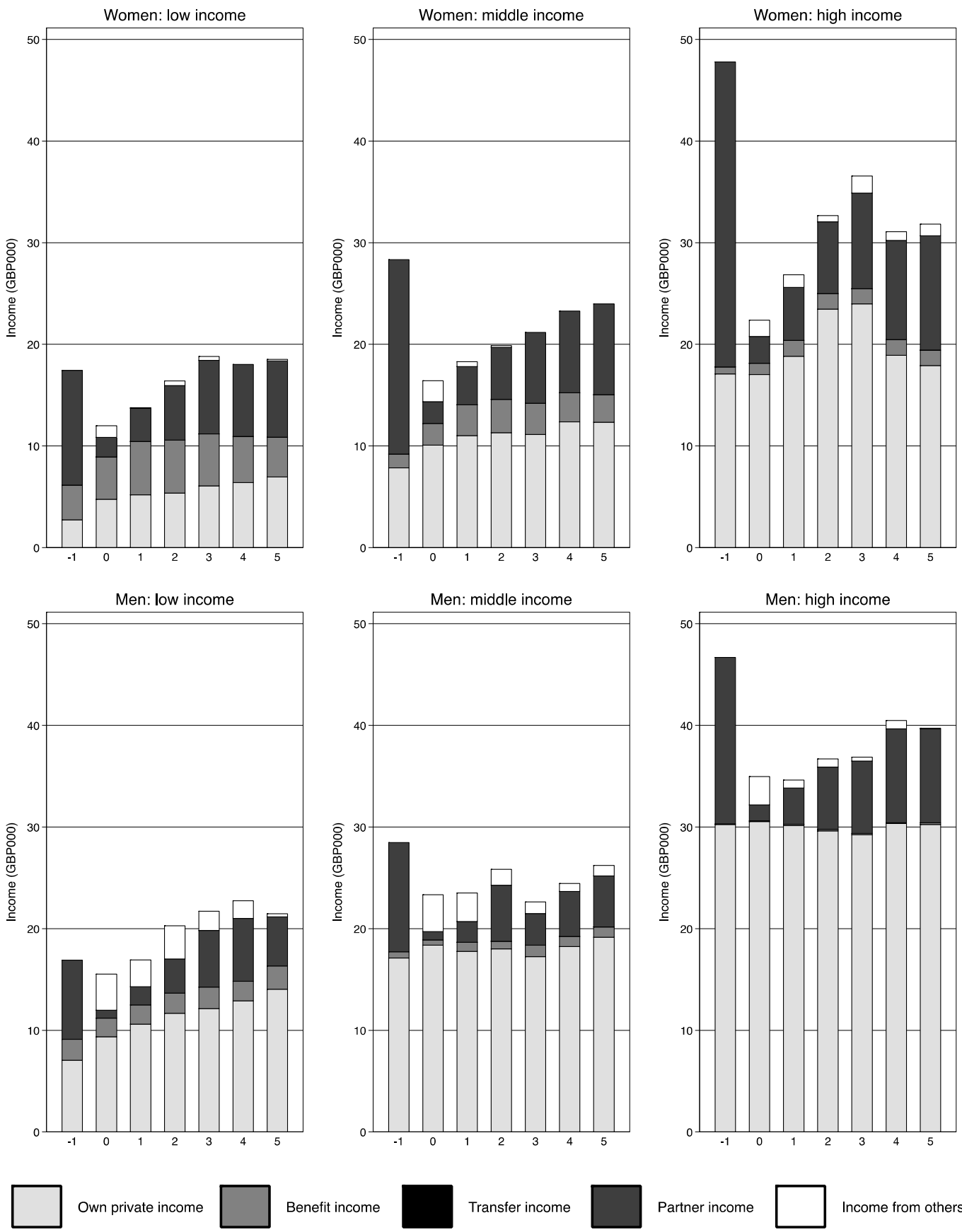

Benefit income

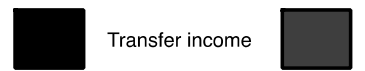

Partner income

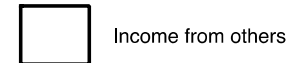

Partner income is the average amount contributed by any coresident partner. At time - 1 this is the former spouse; subsequently it may be a new spouse or a new unmarried coresident partner. It is averaged over all observations regardless of whether a partner is present or not. 


\section{Regression Formula}

In Table 4, we estimate in columns (1) and (5) the following fixed effects regression:

$$
\begin{gathered}
\ln (\text { eq. income })_{i y}^{g}=\beta_{0}^{g} I(t=0)+\beta_{1}^{g} I(t=1)+\beta_{2}^{g} I(t=2)+\beta_{3}^{g} I(t=3)+\beta_{>3}^{g} I(t>3) \\
+\theta_{1}^{g} \text { repartner }+\theta_{2}^{g} \text { related }+\theta_{3}^{g} \text { unrelated }+\theta_{4}^{g} \text { nowork } \\
+\theta_{5}^{g} \text { maint }+\theta_{6}^{g} \text { children }+\theta_{7}^{g} \text { infant }+\gamma_{y}^{g}+\alpha_{i}^{g}+\varepsilon_{i y}^{g}
\end{gathered}
$$

The additional regressors compared to Table 2 above are indicators for various postseparation behaviours that may mitigate the associated income shocks. These include an indicator for moving in with a new partner (repartner), living with related adults (related), living with unrelated adults (unrelated), not having a job (nowork), and receiving maintenance income (maint). We also include regressors indicating the presence of dependent children (children, aged 3 and above) and infants (infant, aged below 3 ) to capture changes in household size that affect the level of equivalised income through the equivalisation factor. In a second set of regressions (columns 2,3,4 and $6,7,8)$ of Table 4 we include interactions between the time-since-divorce and income group and interactions between post-divorce behaviour and income group to examine differences in the importance of behaviours across the income distribution. We do this for separately for men and women.

The fixed effects approach controls for time-invariant individual characteristics. This is particularly important in this second set of regressions: different types of individual are likely to behave in different ways and we want to avoid this difference in types driving our estimates. For example, higher ability men are likely to have higher household incomes and also be less likely to be live with others, but this does not mean that living with others causes household income to fall. We use fixed effects to avoid making this inference. Instead, coefficients are estimated from within individual variation (from individuals who have lived both with others and lived alone), calculating the average difference in equivalised household income in the two living situations for those who have experienced both.

Coefficients on the time since separation indicators ( $t=0$ through to $t>3$ ) are the percentage changes in equivalised household income compared to the five years predivorce if the individual lives alone, is in the labour force and receives no transfers from their former spouse. Coefficients on the post-divorce behavioural variables offset these 
time-since divorce coefficients. For example, for a working woman in the middle income group without any transfers and living along, the loss of equivalised income at the time of divorce is $44 \%$. If she were to repartner, this loss is mitigated by $30 \%$, giving an overall loss of just $16 \%$ at the time of divorce.

Despite the benefits from using a fixed effects approach, these results should still be interpreted as descriptive rather than causal of the lives of divorcing people. For example, we cannot conclude that if someone had repartnered instead of living alone that the recovery in income would be the same as that experienced by those who did repartner. The reason for living alone could be that no high-income new partner could be found, and so the benefit of repartnering available to those who do not repartner would be much lower than the benefit for those who actually did find a high-income new partner.

\section{Results}

Table 4 show that the fall in men's household income is partly mitigated by living with related or unrelated adults: a man's household income would be $13 \%$ lower on average if he did not live with relatives, and 15\% lower if he did not live with unrelated adults, with these effects concentrated amongst men from the lowest pre-divorce income tercile. Those women who do live with other adults also gain from doing so. The fall in women's household income is mitigated by repartnering across the income distribution, adding 36\% to equivalised household income. This suggests that repartnering women from the lowest income group find a new partner who adds around 38\% to their household income, whilst divorce reduced their income by only $19 \%$. In contrast, the new partners of women from the highest income group have income which does not fully compensate for the income lost at divorce.

In contrast, men's equivalised income is not increased by repartnering on average, as their new partner adds just enough household income to offset the increase in household size. There is, however, some heterogeneity across the income groups: the lowest income men see a $29 \%$ income increase ${ }^{22}$ from repartnering, whereas the highest income men experience a 14\% income decrease.

\footnotetext{
22 Significant only at $10 \%$ level
} 
Table 4: Fixed Effects Regressions: Equivalised Household Income

\begin{tabular}{|c|c|c|c|c|c|c|c|c|}
\hline & \multicolumn{4}{|c|}{ Men } & \multicolumn{4}{|c|}{ Women } \\
\hline & $\begin{array}{l}\text { (1) } \\
\text { All }\end{array}$ & $\begin{array}{c}(2) \\
\text { Low } \\
\text { Income } \\
\end{array}$ & $\begin{array}{c}(3) \\
\text { Middle } \\
\text { Income } \\
\end{array}$ & $\begin{array}{c}(4) \\
\text { High } \\
\text { Income }\end{array}$ & $\begin{array}{l}\text { (5) } \\
\text { All } \\
\end{array}$ & $\begin{array}{c}(6) \\
\text { Low } \\
\text { Income } \\
\end{array}$ & $\begin{array}{c}(7) \\
\text { Middle } \\
\text { Income }\end{array}$ & $\begin{array}{c}(8) \\
\text { High } \\
\text { Income } \\
\end{array}$ \\
\hline$t=0$ & $\begin{array}{c}\mathbf{0 . 1 1 7} \\
(0.042)\end{array}$ & $\begin{array}{c}\mathbf{0 . 2 0 6} \\
(0.093)\end{array}$ & $\begin{array}{c}0.118 \\
(0.068)\end{array}$ & $\begin{array}{c}0.056 \\
(0.059)\end{array}$ & $\begin{array}{c}-\mathbf{0 . 4 6 6} \\
(0.042)\end{array}$ & $\begin{array}{c}-\mathbf{0 . 1 9 1} \\
(0.063)\end{array}$ & $\begin{array}{c}-\mathbf{0 . 4 3 9} \\
(0.068)\end{array}$ & $\begin{array}{c}-\mathbf{0 . 7 5 3} \\
(0.088)\end{array}$ \\
\hline$t=1$ & $\begin{array}{c}\mathbf{0 . 1 2 8} \\
(0.049)\end{array}$ & $\begin{array}{c}\mathbf{0 . 2 7 4} \\
(0.114)\end{array}$ & $\begin{array}{c}0.106 \\
(0.076)\end{array}$ & $\begin{array}{c}0.031 \\
(0.060)\end{array}$ & $\begin{array}{l}-\mathbf{0 . 3 5 6} \\
(0.049)\end{array}$ & $\begin{array}{c}-0.124 \\
(0.087)\end{array}$ & $\begin{array}{c}-\mathbf{0 . 3 3 6} \\
(0.072)\end{array}$ & $\begin{array}{c}-\mathbf{0 . 6 0 0} \\
(0.089)\end{array}$ \\
\hline$t=2$ & $\begin{array}{c}\mathbf{0 . 1 6 1} \\
(0.053)\end{array}$ & $\begin{array}{c}\mathbf{0 . 2 7 9} \\
(0.127)\end{array}$ & $\begin{array}{c}\mathbf{0 . 1 7 1} \\
(0.062)\end{array}$ & $\begin{array}{c}0.061 \\
(0.069)\end{array}$ & $\begin{array}{c}-\mathbf{0 . 3 1 1} \\
(0.050)\end{array}$ & $\begin{array}{c}-0.023 \\
(0.079)\end{array}$ & $\begin{array}{c}-\mathbf{0 . 2 8 6} \\
(0.061)\end{array}$ & $\begin{array}{c}-\mathbf{0 . 6 0 0} \\
(0.096)\end{array}$ \\
\hline$t=3$ & $\begin{array}{c}0.080 \\
(0.084)\end{array}$ & $\begin{array}{c}0.140 \\
(0.263)\end{array}$ & $\begin{array}{c}0.052 \\
(0.065)\end{array}$ & $\begin{array}{c}0.035 \\
(0.076)\end{array}$ & $\begin{array}{c}-\mathbf{0 . 2 9 1} \\
(0.055)\end{array}$ & $\begin{array}{c}0.046 \\
(0.068)\end{array}$ & $\begin{array}{c}-\mathbf{0 . 3 2 1} \\
(0.066)\end{array}$ & $\begin{array}{c}\mathbf{- 0 . 5 8 4} \\
(0.117)\end{array}$ \\
\hline$t>3$ & $\begin{array}{c}0.118 \\
(0.068)\end{array}$ & $\begin{array}{c}0.249 \\
(0.157)\end{array}$ & $\begin{array}{c}0.097 \\
(0.068)\end{array}$ & $\begin{array}{c}0.038 \\
(0.083)\end{array}$ & $\begin{array}{c}-\mathbf{0 . 2 8 1} \\
(0.054)\end{array}$ & $\begin{array}{c}0.037 \\
(0.065)\end{array}$ & $\begin{array}{c}-\mathbf{0 . 2 6 3} \\
(0.057)\end{array}$ & $\begin{array}{l}-\mathbf{0 . 6 3 7} \\
(0.098)\end{array}$ \\
\hline Repartner & $\begin{array}{c}-0.032 \\
(0.060)\end{array}$ & $\begin{array}{c}0.290 \\
(0.160)\end{array}$ & $\begin{array}{c}-0.111 \\
(0.076)\end{array}$ & $\begin{array}{c}-0.140 \\
(0.074)\end{array}$ & $\begin{array}{c}\mathbf{0 . 3 5 8} \\
(0.040)\end{array}$ & $\begin{array}{c}\mathbf{0 . 3 7 9} \\
(0.053)\end{array}$ & $\begin{array}{c}\mathbf{0 . 2 9 8} \\
(0.061)\end{array}$ & $\begin{array}{c}\mathbf{0 . 3 8 8} \\
(0.076)\end{array}$ \\
\hline Related adults & $\begin{array}{c}\mathbf{0 . 1 2 7} \\
(0.056)\end{array}$ & $\begin{array}{c}0.184 \\
(0.106)\end{array}$ & $\begin{array}{c}0.071 \\
(0.075)\end{array}$ & $\begin{array}{c}0.041 \\
(0.128)\end{array}$ & $\begin{array}{c}\mathbf{0 . 4 0 6} \\
(0.104)\end{array}$ & $\begin{array}{c}0.241 \\
(0.165)\end{array}$ & $\begin{array}{c}0.278 \\
(0.156)\end{array}$ & $\begin{array}{c}\mathbf{0 . 5 8 0} \\
(0.169)\end{array}$ \\
\hline Unrelated adults & $\begin{array}{c}\mathbf{0 . 1 5 4} \\
(0.060)\end{array}$ & $\begin{array}{c}\mathbf{0 . 2 6 3} \\
(0.126)\end{array}$ & $\begin{array}{c}0.111 \\
(0.120)\end{array}$ & $\begin{array}{c}0.127 \\
(0.089)\end{array}$ & $\begin{array}{c}\mathbf{0 . 3 0 2} \\
(0.071)\end{array}$ & $\begin{array}{c}\mathbf{0 . 3 3 1} \\
(0.123)\end{array}$ & $\begin{array}{c}\mathbf{0 . 4 0 1} \\
(0.123)\end{array}$ & $\begin{array}{c}0.250 \\
(0.146)\end{array}$ \\
\hline Not working & $\begin{array}{c}-\mathbf{0 . 2 9 5} \\
(0.067)\end{array}$ & $\begin{array}{c}-\mathbf{0 . 2 5 1} \\
(0.101)\end{array}$ & $\begin{array}{c}-\mathbf{0 . 4 7 3} \\
(0.110)\end{array}$ & $\begin{array}{c}-\mathbf{0 . 4 0 8} \\
(0.147)\end{array}$ & $\begin{array}{r}-\mathbf{0 . 2 2 5} \\
(0.038)\end{array}$ & $\begin{array}{l}-\mathbf{0 . 2 4 6} \\
(0.049)\end{array}$ & $\begin{array}{c}-\mathbf{0 . 3 0 5} \\
(0.062)\end{array}$ & $\begin{array}{c}-\mathbf{0 . 5 1 0} \\
(0.081)\end{array}$ \\
\hline Receives maintenance & $\begin{array}{c}-0.092 \\
(0.101)\end{array}$ & $\begin{array}{c}-0.053 \\
(0.295)\end{array}$ & $\begin{array}{r}\mathbf{- 0 . 1 1 9} \\
(0.051)\end{array}$ & $\begin{array}{c}\mathbf{0 . 2 0 3} \\
(0.072)\end{array}$ & $\begin{array}{c}0.044 \\
(0.035)\end{array}$ & $\begin{array}{c}0.081 \\
(0.055)\end{array}$ & $\begin{array}{c}0.030 \\
(0.049)\end{array}$ & $\begin{array}{c}0.097 \\
(0.064)\end{array}$ \\
\hline Infants (aged below 3) & $\begin{array}{c}-0.116 \\
(0.062)\end{array}$ & $\begin{array}{c}-\mathbf{0 . 2 8 6} \\
(0.128)\end{array}$ & $\begin{array}{c}-0.080 \\
(0.122)\end{array}$ & $\begin{array}{c}-0.098 \\
(0.084)\end{array}$ & $\begin{array}{r}-\mathbf{0 . 1 2 5} \\
(0.048)\end{array}$ & $\begin{array}{c}-\mathbf{0 . 1 9 3} \\
(0.090)\end{array}$ & $\begin{array}{c}-0.142 \\
(0.082)\end{array}$ & $\begin{array}{c}-0.038 \\
(0.057)\end{array}$ \\
\hline Children (aged 3 and above) & $\begin{array}{c}-\mathbf{0 . 1 3 2} \\
(0.062)\end{array}$ & $\begin{array}{c}-\mathbf{0 . 2 7 1} \\
(0.116)\end{array}$ & $\begin{array}{c}-0.064 \\
(0.112)\end{array}$ & $\begin{array}{c}-0.132 \\
(0.093)\end{array}$ & $\begin{array}{c}-\mathbf{0 . 1 3 5} \\
(0.040)\end{array}$ & $\begin{array}{c}-\mathbf{0 . 1 6 9} \\
(0.066)\end{array}$ & $\begin{array}{c}-\mathbf{0 . 2 0 1} \\
(0.062)\end{array}$ & $\begin{array}{c}-0.070 \\
(0.070)\end{array}$ \\
\hline Observations & 3073 & 817 & 1107 & 1149 & 4267 & 1419 & 1480 & 1368 \\
\hline Individuals & 273 & 74 & 99 & 100 & 368 & 121 & 133 & 114 \\
\hline
\end{tabular}

Regressions include a full set of year indicators, and indicators for presence of children and infants postseparation to capture changes in household structure. Columns 1 and 5, and columns 2-4 and 6-8, are jointly estimated. Robust standard errors clustered by individual in parentheses. Bold indicates significance at $5 \%$ level.

An individual's own labour force participation is an important contribution to both men's and women's household income: if all women were not to work, their household income would be $23 \%$ lower, and for men around $30 \%$ lower. Consistent with the low 
levels of receipt of maintenance transfers described above, receiving a transfer from a former spouse does not lead to a significant increase in income on average. ${ }^{23}$

\section{$5 \quad$ Psychological wellbeing}

Our analysis to this point has described the observed patterns of changes in household income, and investigated the changes in housing as one additional measure of material wellbeing. Both of these aspects suggest substantial declines in wellbeing after divorce, especially for women, that take a long time to recover from. Here we examine psychological wellbeing, as measured by responses to the 12 item General Health Questionnaire (GHQ). This uses the responses to twelve statements to derive a measure of general psychiatric morbidity. This measure has been validated as correlated with clinical assessments of minor psychiatric morbidity, and has often been used as a measure of subjective wellbeing (Goldberg 1992).

Previous studies examining the evolution of wellbeing, as measured by the GHQ, around the time of divorce have found a short run spike in mental distress, reverting to predivorce measures soon after separation (Gardner and Oswald 2006). Whilst parenthood and a mea- sure of neuroticism have been associated with the extent of mental distress experienced, education is not a strong predictor (Tavares and Aassve 2013), and no previous studies have examined the experience at different points in the income distribution.

The overall GHQ score has been normalised to lie between zero and one, with zero representing no mental distress and one representing extreme mental distress. Figure 17 shows the evolution of this measure around the time of divorce. Given the differences in the financial impact of divorce across the income distribution, we might expect that other measures of wellbeing follow a similar pattern.

In line with previous findings, women report a higher level of mental distress than men in general (Bebbington et al. 1998). It is not surprising that divorce is preceded by a steep increase in reports of mental distress, peaking in the year immediately after divorce has occurred (time 0). It is, however, clear that there is a rapid reversion to predivorce GHQ scores from this point, perhaps even achieving lower levels of mental

\footnotetext{
${ }^{23}$ Only four men in the sample ever receive a maintenance transfer.
} 
distress than previously. Experiences across the income distribution are remarkably similar compared to the different income experiences. Most notably, women from the highest income group experience a more dramatic reversion to their pre-divorce wellbeing level despite the far more severe impact on their financial resources.

\section{Figure 17: GHQ scores}

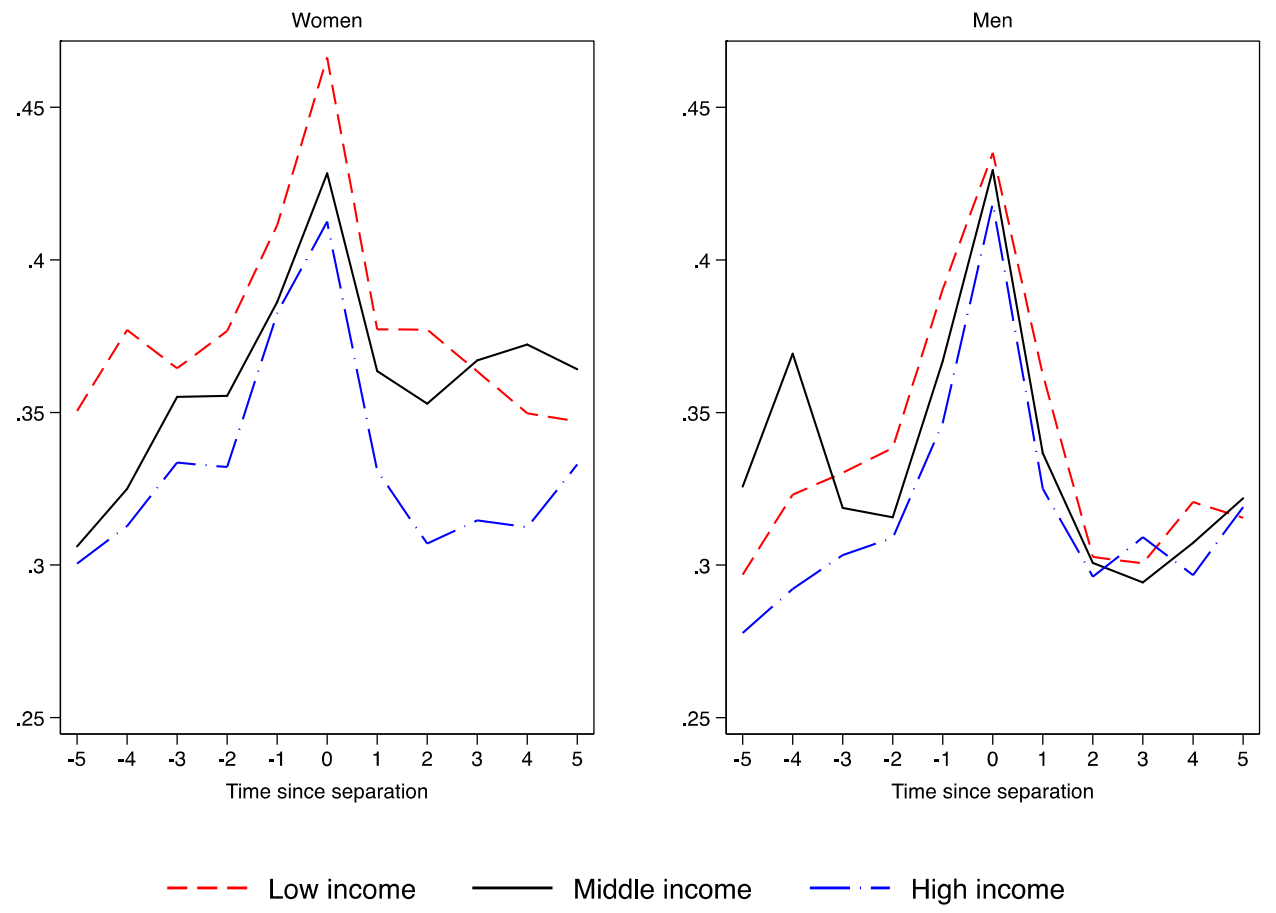

\section{Conclusions}

This paper highlighted the differing experiences of divorce across the income distribution, and for men and for women, in England and Wales. Women lose more than men on divorce, regardless of the pre-divorce level of household income. The highest income women lose out the most and their losses are the most persistent. Among the lowest income women, losses are less and recovery is fastest. Men tend to increase their standard of living on divorce, especially low income men. The other main component of living standards is access to housing. Surprisingly, there is no evidence that women are more likely to remain in the marital home than men, and the majority move house on divorce: around two-thirds of men and two-thirds of women move house within 3 years. There are, however, differences depending on the presence of dependent children. When a divorcing couple has a dependent child at the time of divorce, the woman is 
more likely to remain in the marital home regardless of housing tenure. In contrast, when a divorcing couple does not have dependent children, the man is more likely to remain. Given that this group of couples includes those who have older children who have left home, this raises concerns for the impact of divorce for older women.

Recovery in living standards after divorce comes from repartnering, government benefits and maintenance transfers. The quick recovery among the low income comes partly from repartnering. Maintenance transfers are most important for the group of women from high income households, particularly mothers with dependent children, but even for this group transfers comprise only a very small part of household income. An additional source of support after divorce can come from the extended family. Men, and low income men in particular, appear to rely on support from their extended family: $11 \%$ of men return to living with their extended family after divorce.

It is important to note that our data is drawn from the pre-financial crisis period, ending in 2008. Since then, the economic downturn and changes in economic and social policy may have affected both the financial impact of divorce and the mechanisms available to smooth income shocks. For example, as benefit generosity fell, this would be less effective at insulating women from the income shock of relationship breakdown; as the 'bedroom tax' ${ }^{24} 23$ is implemented, the ability to temporarily move in with family or other adults may be reduced; and after legal aid cuts the divorce process itself may impose greater costs or be less effective at balancing competing needs and interests. Future research should use more recent data to examine the impact of these economic and policy changes.

Our main focus on the consequence of divorce has been on income, adjusted to reflect the size of the household, and the housing tenure of the household. The most important pieces of missing information are the net asset position of the household and pension provision. Further, to evaluate the welfare effects of divorce, we need to understand the extent of income sharing within marriage, and in extended family households postdivorce.

\footnotetext{
${ }^{24}$ This is a tax on unused capacity in housing provided or subisdised by the state.
} 


\section{References}

Aassve, A., Betti, G., Mazzuco, S., \& Mencarini, L. (2007). Marital disruption and economic well-being: a comparative analysis. Journal of the Royal Statistical Society: Series A (Statistics in Society), 170(3), 781-799.

Andreß, H.-J., Borgloh, B., Brockel, M., Giesselmann, M., \& Hummelsheim, D. (2006). The economic consequences of partnership dissolution: a comparative analysis of panel studies from Belgium, Germany, Great Britain, Italy, and Sweden. European Sociological Review, 22(5), 533-560.

Avellar, S., \& Smock, P. J. (2005). The economic consequences of the dissolution of cohabiting unions. Journal of Marriage and Family, 67(2), 315-327.

Bebbington, P. E., Dunn, G, Jenkins, R, Lewis, G, Brugha, T, Farrell, M, \& Meltzer, H. (1998). The influence of age and sex on the prevalence of depressive conditions: report from the national survey of psychiatric morbidity. Psychological medicine, 28(01), 9-19.

Bianchi, S. M., Subaiya, L., \& Kahn, J. R. (1999). The gender gap in the economic wellbeing of nonresident fathers and custodial mothers. Demography, 36(2), 195203.

Bonnet, C., Garbinti, B., \& Sola, A. (2015). Do women really bear the cost of divorce? The role of child custody, public and private transfers in France.

Bratberg, E., \& Tjøtta, S. (2008). Income effects of divorce in families with dependent children. Journal of Population Economics, 21(2), 439-461.

Brewer, M., \& Nandi, A. (2014). Partnership dissolution: how does it affect income, employment and well-being? Institute for Social and Economic Research, University of Essex, (2014-30).

Bryson, C., Skipp, A., Allbeson, J., Poole, E., Ireland, E., \& Marsh, V. (2013). Kids aren't free: the child maintenance arrangements of single parents on benefit in 2012.

de Vaus, D., Gray, M., Qu, L., \& Stanton, D. (2014). The economic consequences of divorce in Australia. International Journal of Law, Policy and the Family, 28 (1): 26-47. 
Department for Work and Pensions. (2015). Households below average income (HBAI) quality and methodology information report 2013/14.

Dewilde, C. (2008). Divorce and the housing movements of owner-occupiers: a European comparison. Housing Studies, 23(6), 809-832.

Duncan, G. J., \& Hoffman, S. D. (1985). A reconsideration of the economic consequences of marital dissolution. Demography, 22(4), 485-497.

Eekelaar, J., \& Maclean, M. (1986). Maintenance after divorce. Oxford University Press, USA.

Feijten, P. (2005). Union dissolution, unemployment and moving out of homeownership. European Sociological Review, 59-71.

Fisher, H., \& Low, H. (2009). Who wins, who loses and who recovers from divorce? Sharing Lives, Dividing Assets, Hart Publishing.

Fisher, H., \& Low, H. (2015). Financial implications of relationship breakdown: does marriage matter? Review of Economics of the Household, 1-35.

Gadalla, T. M. (2008). Impact of marital dissolution on men's and women's incomes: a longitudinal study. Journal of Divorce \& Remarriage, 50(1), 55-65.

Gardner, J., \& Oswald, A. J. (2006). Do divorcing couples become happier by breaking up? Journal of the Royal Statistical Society: Series A (Statistics in Society), 169(2), 319336.

Goldberg, D. (1992). A classification of psychological distress for use in primary care. Social Science and Medicine, 35(2), 189-193.

Holden, K. C., \& Smock, P. J. (1991). The economic costs of marital dissolution: why do women bear a disproportionate cost? Annual Review of Sociology, 51-78.

Jarvis, S., \& Jenkins, S. P. (1999). Marital splits and income changes: evidence from the British Household Panel Survey. Population Studies, 53(2), 237-254.

Jenkins, S. P. (2008). Marital splits and income changes over the longer term. Changing Relationships.

Kiernan, K., \& Mueller, G. (1998). The divorced and who divorces?

Maclean, M., \& Eekelaar, J. (1997). The parental obligation. Oxford Univ Press. 
Manting, D., \& Bouman, A. M. (2006). Short-and long-term economic consequences of the dissolution of marital and consensual unions. the example of the Netherlands. European Sociological Review, 22(4), 413-429.

McKeever, M., \& Wolfinger, N. H. (2001). Reexamining the economic costs of marital disruption for women. Social Science Quarterly, 202-217.

McManus, P. A., \& DiPrete, T. A. (2001). Losers and winners: the financial consequences of separation and divorce for men. American Sociological Review, 246-268.

Mulder, C. H., \& Wagner, M. (2010). Union dissolution and mobility: who moves from the family home after separation? Journal of Marriage and Family, 72(5), 1263-1273.

Ongaro, F., Mazzuco, S., \& Meggiolaro, S. (2009). Economic consequences of union dissolution in Italy: findings from the European Community Household Panel. European Journal of Population/Revue europeenne de Demographie, 25(1), 45-65.

Poortman, A. (2000). Sex differences in the economic consequences of separation a panel study of the Netherlands. European Sociological Review, 16(4), 367-383.

Smock, P. J. (1994). Gender and the short-run economic consequences of marital disruption. Social Forces, 73(1), 243-262.

Tamborini, C. R., Couch, K. A., \& Reznik, G. L. (2015). Long-term impact of divorce on women's earnings across multiple divorce windows: a life course perspective. Advances in Life Course Research.

Tavares, L. P., \& Aassve, A. (2013). Psychological distress of marital and cohabitation breakups. Social Science Research, 42(6), 1599 -1611.

Uhrig, S. (2008). The nature and causes of attrition in the British Household Panel Study. 